\title{
WestVirginiaUniversity
}

THE RESEARCH REPOSITORY @ WVU

Graduate Theses, Dissertations, and Problem Reports

2017

\section{Between a Bear and an Eagle: Soviet Arms and the U.S. Response in Peru}

William Horacek

Follow this and additional works at: https://researchrepository.wvu.edu/etd

\section{Recommended Citation}

Horacek, William, "Between a Bear and an Eagle: Soviet Arms and the U.S. Response in Peru" (2017). Graduate Theses, Dissertations, and Problem Reports. 5821.

https://researchrepository.wvu.edu/etd/5821

This Thesis is protected by copyright and/or related rights. It has been brought to you by the The Research Repository @ WVU with permission from the rights-holder(s). You are free to use this Thesis in any way that is permitted by the copyright and related rights legislation that applies to your use. For other uses you must obtain permission from the rights-holder(s) directly, unless additional rights are indicated by a Creative Commons license in the record and/ or on the work itself. This Thesis has been accepted for inclusion in WVU Graduate Theses, Dissertations, and Problem Reports collection by an authorized administrator of The Research Repository @ WVU. For more information, please contact researchrepository@mail.wvu.edu. 
Between a Bear and an Eagle: Soviet Arms and the U.S. Response in Peru

\author{
William Horacek
}

Thesis submitted to the Eberly College of Arts and Sciences at West Virginia University

In partial fulfillment of the requirements for the degree of

Master of Arts in

Diplomatic History

\author{
Jim Siekmeier, Ph.D., Chair \\ Elizabeth Fones-Wolf, Ph.D. \\ Michelle Stephens, Ph.D. \\ Department of History \\ Morgantown, West Virginia \\ 2017
}

Keywords: Diplomatic History, Soviet Union, Peru, United States, Peruvian-United States Relations, Cold War, Velasco, Nixon, Soviet Arms Copyright 2017 William Horacek 


\begin{abstract}
Between a Bear and an Eagle: Soviet Arms and the U.S. Response in Peru
\end{abstract}

This research looks at the left-leaning military government of Juan Velasco Alvarado of Peru ruled from 1968 to 1975. This government embarked on a crusade to modernize Peru through a series of reforms and changes in Peruvian foreign policy. The United States responded with non-overt economic pressure, and the ending of military sales to Peru. Peru bought weaponry from the Soviet Union against the wishes of the United States in 1973, and this resulted in a more conciliatory foreign policy from the United States towards the Andean nation. The shifting foreign policy is the opposite of how historians have characterized relations between the United States and Latin America.

My research contributes to the historiography of United States-Peruvian Relations by expanding on very limited coverage of the Velasco period. This is examined through a regional, high level diplomatic, and economic lens. This thesis argues that the United States is willing to work with left leaning Latin American governments if expropriated companies are properly compensated.

This period in American-Peruvian history is incredibly important to explaining the motivations and goals in U.S. foreign policy. The examination of Soviet Arms in Peru, and Peru's work in the early Drug War is a new addition to the historiography of this subject. 
Table of Contents

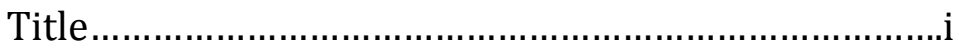

Abstract...................................................................ii

Table of Contents .....................................................ii

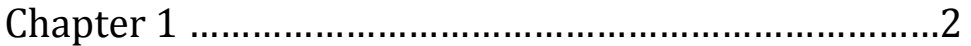

Chapter 2: Peru meets its Northern

Neighbor.

11

Chapter 3: The Institutional Revolution in Peru 1968-1972 and the U.S. Response

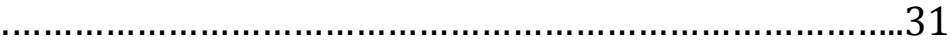

Chapter 4:

The first Soviet Military Sales in South America: Peruvian Agency in US-Peruvian

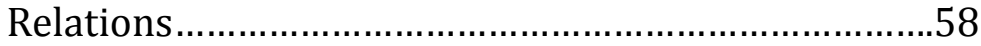

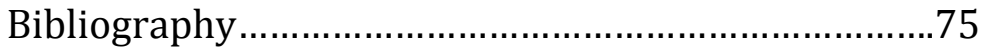




\section{Chapter 1}

The United States and Peru have enjoyed an unusually beneficial relationship compared to nearly all other Latin American countries. ${ }^{1}$ This connection is largely based on the close ties between Peru and the United States military. The United States wanted a strong ally in South America to maintain influence in the continent, and Peru wanted an alliance with the United States to increase trade and counter the power of Chile. The military bond began during the War of the Pacific in the late 1870s and became truly foundational to Peru after the First World War. This alliance inadvertently helped to create the military dictatorship of Juan Velasco Alvarado in 1968 also known as the Institutional Peruvian Revolution. This revolution was one of the stranger episodes in Latin American history as this was a military regime based upon left leaning principles. Even more remarkably U.S. leaders responded rather benevolently to Peru's decision to buy Soviet weapons in 1973. However strains persisted. Peru expropriated U.S. companies; it made a sharp turn towards encouraging investment from other countries besides the United States and attempted comprehensive land reform. Previous narratives of the Peruvian Revolution provide little detail on the Soviet arms that entered into Peru and their significance. The Soviet arms played an important part of the foreign policy experience during this time period and showed the flexibility of the United States' diplomacy towards Peru. U.S. foreign policy in Latin America focused upon compensation for expropriation, pragmatic realism,

${ }^{1}$ The majority of historians will agree that the history of U.S.-Latin American nations in the $20^{\text {th }}$ century is generally the story of imperialism, interventions, economic domination, and Cold War antagonisms mixed with periods of pan-Americanism and reconciliation. Peru's experience in the $20^{\text {th }}$ century included many of the conflicts, but the United States treated the Andean nation with general benevolence. 
and anti-communism. Peru exploited these goals by playing the United States off the Soviet Union to maintain and increase its power in Latin America, and the global community during the Cold War.

The United States accommodated Peru during the revolution for a few simple reasons. The United States badly needed an ally in the region to confront growing Marxism in the Andes. In 1970, Chile became the first Latin American country to have a Marxist led government . Left leaning presidents came to power in Bolivia and Ecuador at roughly the same period, and the United States needed to retain an overall positive relationship with Peru to keep the situation from spiraling out of U.S. control Secondly, Peru and the United States held an important relationship prior to the 1968 revolution. Lastly, Peru sufficiently compensated the businesses that it expropriated. This provided an important example to other Latin American Governments how capitalism should be respected.

There is relatively little written about in U.S.-Peruvian relations in the late 1960s and early 1970s particularly in comparison to the numerous volumes dedicated to the United States' experience in Chile during the same years. Richard Walter's Peru and the United States, 1960 -1975: How Their Ambassadors Managed Foreign Relations in a Turbulent Era is by far the most important book on the subject. Walter argued that Nixon's trust in military governments and the work of Peruvian ambassadors enabled Peru to follow a more independent course in foreign policy. ${ }^{2}$ Abraham Lowenthal's The Peruvian Experiment and with Cynthia McClintock The Peruvian Experiment Reconsidered are both exceptionally helpful for understanding the goals, successes, and failures of the revolution

2 Richard Walter, Peru and the United States, 1960-1975: How their Ambassador Managed Foreign Relations in a Turbulent Era (University Park: Pennsylvania State University, 2010), 12. 
in economic and ideological terms. ${ }^{3}$ In these key works, Lowenthal carefully analyzed the key ideologies of Peruvian nationalism and communism and how they changed from the pre=Velasco to the Velasco to the post-Velasco eras.

Frederick Pike's The United States and the Andean Republic's characterizes the late 1960s and 1970s as an era where many South American governments attempted to escape their dependency on the United States. Peru is shown to be a nation where nationalism and non-US foreign capital was promoted at the same time. ${ }^{4}$ An excellent example is the payment of compensation to expropriated companies and the dramatic rise of foreign investment during Velasco's tenure. The United States and the Andean Republic's true importance is its focus on the regional situation in Latin America and its effect upon U.S. diplomacy. The author argues that the increased hostility to U.S. interests in the Andes from Chile's Salvador Allende, Peru's Velasco, and the numerous left leaning military governments in Ecuador limited what the United States was able to do against Peru. These governments distrusted the framework of the Alliance for Progress that encouraged workers to be independent from the government. Latin American leaders preferred to have the people dependent on the government to maintain control. This created a fascinating dynamic where governments in Latin America depended greatly on the United States for economic stability but could also use this dependence to propagate the entrenched antiAmericanism in their nations. Peru derived great strength from this dependency while exploiting the fact that the United States also depended on Peru's role stabilizing a pro-U.S.

\footnotetext{
${ }^{3}$ Abraham Lowenthal and Cynthia McClintock, The Peruvian Experiment Reconsidered (Guildford: Princeton University Press, 1983), 22. ${ }^{4}$ Frederick Pike, The United States and the Andean Republics: Peru, Bolivia, Ecuador (Cambridge: Harvard University Press), 347.
} 
stance in the region. Pike's seminal work redirected the historiography toward a focus on the regional perspective rather than the simply an examination of a Latin American nation.

Lowenthal was more interested in measuring the success of the Peruvian Revolution than examining the regional situation in the Andes. Lowenthal stated that the revolutionary government failed in both economic and reformist goals. He only briefly addressed USPeruvian relations, focusing primarily on the anti-US corporate sentiment held by many Peruvians who were exploited by the military government. Cynthia McClintock co-authored the former book and also co-authored Peru and the United States: Cooperation at a Cost, which argues that even though the cooperation has existed since the 1820s, it has only diverged a small number of times since then. ${ }^{5}$ She argued that this relationship became more strained during the Velasco period, but Velasco and his government understood that in order to stay in power they would have to play a game of improving and diminishing U.S. relations to use as a bargaining chip against the "Colossus of the North."

Moving to an examination of key players, Richard Walter examines the relationship through a high level diplomatic focus that attributes the leniency of U.S. policy to the need of the United States for an ally in the region. The Nixon administration believed that military regimes in Latin America could be trusted to be pro-U.S., stabilizing forces in the region far more because they held power more firmly than civilian governments. Walter's work helped to direct focus on diplomacy as a way to examine the Peruvian-U.S. relationship.

Allende's Chile and the Inter-American Cold War by Tanya Harmer continued Pike's work by putting the presidency of Salvador Allende in the 1970s into the regional context

${ }^{5}$ Cynthia McClintock and Fabian Vallas, The United States and Peru: Cooperation at a Cost (New York: Routledge Press, 2003), 8. 
of Latin America's Cold War. ${ }^{6}$ Harmer argues that the United States played less of a role in the downfall of the Allende government than previously thought. She also states that the military government of Brazil as well as Chilean conservatives influenced the situation far more than other historians have attributed. Harmer concludes that the main reason that Chile's relations with the United States were tense, and Peru's were not, was because Peru compensated investors after expropriation.

Hal Brands' article, "The United States and the Peruvian Challenge, 1968-1975" is a post-revisionist ${ }^{7}$ examination into the diplomatic difficulties of the leftist regime. Brands concludes that several different factors enabled Peru to gain the upper hand in foreign policy and forced the United States to treat Velasco as an ally in the region. These factors included the need for a friend in South America, Peru's repayment of expropriated properties, fear of driving Peruvians to the Soviets, and the willingness of Peruvians to work with the United States. ${ }^{8}$

Lawrence Clayton's Peru and the United States: The Condor and the Eagle states that there have been four different frameworks used to explain the relations between the United States and Peru. ${ }^{9}$ The first is the traditional asymmetrical framework where the United States and business interests dominated the relationship and successfully maintained this position throughout the $20^{\text {th }}$ century. The second framework is the dependency theory stating that Peru has been subject to world forces that put it within the

${ }^{6}$ Tanya Harmer, Allende's Chile and the Inter-American Cold War (Chapel Hill: University of North Carolina Press, 2011), 17.

7 Post-Revisionism in US-Latin American Diplomacy argues that the United States' hegemony is greatly due to compliant elites in Latin America and their governments. ${ }^{8}$ Hal Brands, "The United States and the Peruvian Challenge, 1968-1975" Diplomacy \& Statecraft 21 (2010): 472.

${ }^{9}$ Lawrence Clayton, Peru and the United States: The Condor and the Eagle (Athens: University of Georgia Press, 1999), 10. 
overwhelming power of the United States. However the author goes further with this to create a post-dependency model in which he states that Peru has domestic factors such as American owned businesses causing it to be greatly influenced by the United States. The third framework is the ambivalent feelings that Peru has towards the United States. Peruvians embraced American culture, products and capital, but voices of dissent would pop up to change their own foreign policy. The final framework suggests that the two countries generally share the same conceptions of liberty and equality but occasionally diverged, resulting in a tumultuous relationship for a period. Clayton concludes that the Velasco regime remained hostile to the United States for its entirety, and its most lasting impact was the destabilization of the region by the heightened fear of war in the 1970 s. $^{10}$ The expropriation of the International Petroleum Company, Cerro de Pasco, Anderson Clayton, and Casa Grace by the Velasco regime played an important role in Clayton's narrative by showing the extreme nationalism of Velasco and the Peruvian people. However, this book does not address the levels of accommodation shown to Peru by the United States. The historiography of the Velasco regime will continue to grow as U.S. diplomatic and military documents continue to be declassified.

This thesis builds upon the work of Tanya Harmer and Frederick Pike to see the 1970s as a critically important period regionally in Latin America for U.S. policy. The Soviet arms are not just a footnote in the history of the Velasco regime. Their introduction to Peru had a direct influence on the changing policy of the United States on the Latin American nation. The non-overt economic pressure that had been sustained since 1969 by the Nixon administration shifted to a more conciliatory foreign policy in September 1973 after Peru

10 Lawrence Clayton, Peru and the United States: The Condor and the Eagle (Athens: University of Georgia Press), 256. 
announced that it had purchased weapons from the Soviet Union. The issue of Soviet Arms has been largely ignored in past narratives. This is due to classification issues with documents and past historians' focus on Chile's Marxist leader, Allende, in terms of Soviet relations with Latin America. The entrance of Soviet arms into Peru posits an important question to historians. Why did the United States allow the recalcitrant nation to obtain such weapons without enacting harsh penalties? The most direct answers are pure economics and ideology. Compensation for expropriated businesses and the disavowal of Marxism gave the Velasco government the ability to survive its move away from U.S. influence while Allende's Chile could not. U.S. officials apparently agreed with U.S. businessmen that the economic sanctions were actually counterproductive and changed the punitive policies. The regional situation of Latin American politics in the early 1970s forced the United States to accept left leaning allies in its fight against communism. Leftists came to power in Ecuador, Bolivia, and Peru during this period, and President Nixon did not react the same way to these nations as he did to Chile. Peru's unusual left leaning military dictatorship allowed the nation to move away from the United States while simultaneously negotiating with its traditional ally to keep essential support flowing. The Peruvian experiment ended in August of 1975, but the legacy of Juan Velasco Alvarado continued with the recent Leftist president Ollanta Humala from 2011 to 2016.

Finally, there has been relatively little written focusing on Peruvian agency in this relationship. Walters' Peru and the United States, $1960-1975$ is by the far the most comprehensive and important work in the historiography that focuses on the direct actions of the military government in how U.S. foreign policy developed during those years. Frederick Pike's The United States and the Andean Republics is seminal in introducing the 
regional aspect, but it does not highlight the role of Latin Americans enough.

This work is adding to a trend in the historiography that highlights Latin American agency in the shaping of U.S. foreign policy. Hal Brands' Latin America's Cold War and James Siekmeier's Bolivian Revolution and the United States place a far greater importance on the actions of elite and non-elite Latin Americans in the shaping of Cold War politics in the Western Hemisphere than previous authors. Alan McPherson's The Invaded examines Latin American responses to U.S. military invasions in the early 1900s to explain the eventual end of this form of imperialism. These works have contributed to the trend of adding the importance of work done by Latin Americans to the historiography of U.S. foreign relations. The diplomatic finesse by the Peruvian government during the late 1960s and early 1970s directly contributed to U.S. accommodation to the regime. Any examination into U.S. foreign policy is insufficient without studying the actions and intentions of the foreign power.

\section{Thesis Organization}

The first chapter focuses on the military and political connections between Peru and the United States prior to the Peruvian Revolution in 1968. This includes the political clashes that helped create the revolution such as U.S. support for a political group hated by the Peruvian military, refusals by the United States to supply napalm to the Peruvian army, and the conflict over an infamous oil company. The second chapter details what the Peruvian Revolution attempted to accomplish and how these activities promoted independence from the United States. The chapter also focuses on the direct line of events 
from Chile's devastating 1970 earthquake to its election of Allende as president - all occurring the same year Peru began purchasing Soviet arms. The final chapter expounds upon the work of the previous chapter, but spotlights the direct cause and effect of the Soviet arms deal on U.S. foreign policy. 
Chapter 2

Peru meets its Northern Neighbor

The history before the 1968 Revolution is made up of three historical periods that exhibit the shifts in the U.S.-Peruvian relationship. From 1879-1941, the United States played a rather limited role in Peruvian affairs but the relationship found its beginning during the War of the Pacific and the naval mission during the Augusto Leguía presidencies. The second period spanning from 1941-1957 saw the United States gaining vast power in Latin America with the nation becoming the primary supplier of military equipment and the most important trading partner for the region. These military sales were meant to create a stable government in Peru while creating a dependence on the United States for the supplies. The final period from 1958-1968 saw the most dramatic shift in U.S.-Latin American relations. The era began with Nixon's rocky trip in 1958 followed by the Cuban Revolution the next year. The United States and Peru found their relationship increasingly troubled until the breaking point in 1968. The United States wanted to maintain economic and military dependence in Peru while the Peruvian government needed this support to remain in power. The increase in economic nationalism in Peru drove a wedge between the two countries. Few nations can trace such a long and beneficial relationship, but stark differences would become apparent after the Peruvian revolution of 1968.

The first military connection between the United States and Peru began during a Chilean, Peruvian, and Bolivian conflict known as The War of the Pacific, 1879-1881. In 1879 the War of Pacific erupted over control of the lucrative guano and nitrate industry in a disputed region between Chile and Peru and subsequently Bolivia was brought into the 
war on the side of Peru through an earlier defensive pact. ${ }^{11}$ Businessmen from the United States sold arms to both sides during the war and a few veterans of the American Civil War served in the rival armies. The United States attempted to mediate between the powers six different times but failed disastrously due to poor diplomacy, a change in the presidency, and congressional disapproval. ${ }^{12}$ The United States hoped that mediation would be an important foothold for American power in the region while Peru hoped the United States would provide a lenient decision after the war. However, the U.S. government ended up serving as a mediator. The Treaty of Ancón in 1883 ended hostilities, but Peru's loss of the Tacna, Arica, and Tarapaca regions in the south lead to future problems as Peru would demanded the return of these areas.

In 1896 the first foreign military officers arrived in Peru, but rather than coming from the Americas they arrived from France. ${ }^{13}$ The Escuela Superior de Guerra, Escuela de Caballería, Escuela de Infantería, Escuela de Artillería all fell under the modeling and authority of French officers well into the 1920s. France's influence profoundly shaped the army until 1940 when World War II brought the United States to support the Peruvian army. The French also sponsored a naval mission from 1905-1912, as well as a disappointing aviation mission, mission of a creation of a Peruvian Air Force, at the end of 1910s. However, the greatest impact of France's support in the armed forces came from the military schools that the French had championed. World War One ended the dominance of

\footnotetext{
11 Peter Flindell Klarén, Peru: Society and Nationhood in the Andes, (Oxford: Oxford University Press, 2000), 185.

12 Lawrence Clayton, Peru and the United States: The Condor and the Eagle, 61.

${ }_{13}$ Dirk Kruijit, Revolution by Decree: Peru 1968-1975 (West Lafayette: Purdue University Press, 2003), 31.
} 
France in the affairs of Peru, and gave the United States the world standing that South America found useful.

Peru hoped to gain U.S. support for reclamation of the territories of Arica and Tacna lost to Chile during the War of the Pacific. Peru sought to use the naval mission to weaken any Chilean resistance to this plan. This support materialized under the presidency of Calvin Coolidge when General John J. Pershing arrived in Arica in 1925 to decide how to settle the dispute. ${ }^{14}$ Pershing worked for over a year until health reasons forced him home, but his replacement's efforts culminated in the Treaty of Lima in 1929. Chile received Arica, Peru regained Tacna, and Chile paid Peru six million as an indemnity. Peru and Chile celebrated moderately, they were decidedly happy that this almost fifty year argument had come to a close. This came at the same time as U.S. mediation over Peru's border with Colombia. However, Peru unhappily felt that it had to accept the Colombian border settlement to please the United States in order to reach the Treaty of Lima. ${ }^{15}$ This was the start of contention between the US and Peru.

The institutional beginning of the US-Peruvian military connection began under the presidency of Augusto Leguía, who served from 1908 to 1912 and then again from 19191930. Leguía asked his counterpart in the United States, Woodrow Wilson, to establish a naval mission to train and modernize the Peruvian navy. ${ }^{16}$ This arrangement pleased both sides as the increasingly bloody and financial cost of controlling the hemisphere was

\footnotetext{
${ }^{14}$ Lawrence Clayton, Peru and the United States: The Condor and the Eagle, 139.

${ }^{15}$ Frederick Pike, The United States and the Andean Republics, 203.

${ }^{16}$ Joel Christenson, "From Gunboats to Good Neighbors: U.S. Naval Diplomacy in Peru, 1919-1942 " Ph.D Dissertation, West Virginia University, 2013, 38.
} 
becoming a problem for the United States and Peru hoped that closer ties to the Colossus of the North would bring foreign investment. ${ }^{17}$

Along with these military missions, Peru welcomed an economic mission from the United States. Edwin Kemmerer, a Princeton economist known as the "Money Doctor", visited the Andean nations in the 1920s to promote a series of financial reforms to improve government functions and the economies of the Andean nations. These reforms consisted of cutting government programs and employees, paying the national debt, and lowering taxes on businesses. The Great Depression would end the Andean governments' trust in the reforms.

The U.S. military mission in 1920 proved to be a success for the navy of Peru, and the mission only solidified the eleven-year reign, Oncenio, of Augusto Leguía. The U.S. navy based its modernization on three distinct goals; building the power of the Peruvian navy through submarines, creating a naval academy based upon the US Naval Academy in Annapolis, Maryland, and creating an aviation corps run by the Peruvian Navy. ${ }^{18}$ The United States made this modernization possible by granting loans to the Peruvians in order to purchase American-made armaments and by Peruvian acceptance of an American economist, William W. Cumberland, as administrator of Peruvian customs. ${ }^{19}$ Four type R submarines, a naval academy, and an aviation program based around three Boeing-made training planes made Peru a far more formidable force in Latin America. However, Leguía's fall from power in 1930 forced the United States to give up most of its military influence,

17 The U.S. stationed troops in Nicaragua from 1912 to 1925 and again from 1926-1933. Thomas W. Walker and Christine J. Wade, Nicaragua: Living in the Shadow of the Eagle (Boulder: Westview Press, 2011), 18.

18 Joel Christenson, "From Gunboats to Good Neighbors: U.S. Naval Diplomacy in Peru, 1919-1942," 68.

${ }^{19}$ Christenson, "From Gunboats to Good Neighbors," 94. 
and the Great Depression created a great deal of anti-U.S. sentiment that France and fascist Italy happily exploited. During the Great Depression, Peru turned to fascist Italy from 19371941 to help their Air Force by welcoming Italian aviation missions, but there is little evidence of long-term influence from Italy. ${ }^{20}$ France continued its programs in the army until 1940. American influence in the armed services gained a lasting foothold with effects that would continue throughout the century.

The end of World War II brought far closer ties to the United States as Peru became a major recipient of U.S. military aid second only to Chile. ${ }^{21}$ No other nation had the capability to supply Latin America with arms and equipment during and after the Second World War, and the United States happily used the opportunity to consolidate power in the region. This military and economic relationship greatly helped the economies and political elite in Latin America. Peru supported the UN war effort in Korea and profited from the increased price of copper and tin caused by the conflict. Under the Mutual Assistance agreement of 1952, Peru and agreed to limit trade with communist nations, and agreed that the United States would be the primary supplier of military hardware for the Latin American nation. ${ }^{22}$

\section{Cold War and US-Peruvian Relations}

Between 1950 and 1965 the Peruvian government received over 59.3 million dollars in military grants from the United States government. This statistic is even more

\footnotetext{
${ }^{20}$ Ronn Pineo, Ecuador and the United States: Useful Strangers (Athens: University of Georgia Press, 2007), 110.

21 Daniel Sharp, U.S. Foreign Policy and Peru (Austin: University of Texas Press, 1972), 38

22 James Carey, Peru and the United States, 1900-1962 (Notre Dame: University of Notre Dame Press, 1964), 143.
} 
impressive when combined with the fact that over seventy five percent of Peruvian officers who trained overseas studied in either the Panama Canal Zone or the United States mainland. ${ }^{23}$ This coincided with the establishment of the Center for High Military Studies, Centro de Altos Estudios Nacionales or CAEM, by the dictatorship of Manuel Odría in 1950. The CAEM based itself on the War College in Pennsylvania and the earlier French academies. The army became particularly close to French doctrine as all the officers connected to the 1968 coup attended the CAEM, absorbing the theory that officers should be technocrats as well as leaders. The leaders of the Peruvian Revolution of 1968 drew many of their ideals from their experiences at the CAEM. The army schools commissioned and promoted officers based largely on academic performance and encouraged students to believe that the Peruvian army should play a pivotal role in improving the lives of Peruvians. Director of the CAEM, José del Carmen Marín Arista, developed a curriculum that taught that national security involved addressing the poverty of its citizens. ${ }^{24}$ The military believed that they would have to modernize Peru in order to prevent communist uprisings. Fostering paternalism rather than self-sufficiency dominated the political thinking of the academy. Julio Cotler's chapter in The Cambridge History of Latin America remarks that U.S. officials understood that power in Peru resided among the large landowners, bankers, and the North American companies..$^{25}$ It would become hard for the U.S. to argue that change in Peru was not necessary. The Center for Higher Military Studies' philosophy is easily seen through Cotler's chapter. Here students learned that the military

${ }^{23}$ Daniel Sharp, U.S. Foreign Policy and Peru, 45.

24 Dirk Kruijt, Revolution by Decree: Peru 1960-1975, 36.

${ }^{25}$ Julio Cotler, The Cambridge History of Latin America (Cambridge: Cambridge University Press, 2008), 281. 
would have to play an extremely important role in the modernization and forging of a more economically and socially equitable Peru.

Another important factor in US-Peruvian relations was the Alianza Popular Revolucionaria Americana or APRA. The United States covertly funded the Alianza Popular Revolucionaria Americana or APRA's founder's , Victor Raúl Haya de la Torre, bids for political office. ${ }^{26}$ The APRA party was founded 1924 on a platform of anti-imperialism, panAmericanism, and economic nationalism with the hope that every Latin American nation would start its own APRA party. The petty Bourgeoisie and urban workers who constituted the majority of APRA members wanted to regain power from the ultra wealthy, and reverse the unequal modernization of the twentieth century. ${ }^{27}$ Haya's platform predicated itself on the belief that rulers should be enlightened, but with a dominating power to both defeat its enemies and inspire unconditional public support. Despite the similarity with later ideology espoused by the military, the Peruvian army never identified with APRA. When Haya lost the Peruvian election for president in 1931, Aprístas turned to violence. A prison in Trujillo captured by the revolutionaries became the sight of gruesome executions of dozens of members of the army and civil guard. ${ }^{28}$ The army responded with a massacre of thousands of APRA supporters in the shadow of the ancient city of Chan-Chan. Tensions continued to grow worse as the APRA attempted to foment revolution in the Navy by convincing sailors to mutiny in $1948 .{ }^{29}$ The military responded by bringing to power Manuél Odría, and overthrowing the president José Bustamente who had held office since

${ }^{26}$ Richard Walter, Peru and the United States, 1960-1975: How their Ambassador Managed Foreign Relations in a Turbulent Era (University Park: Pennsylvania State University, 2010), 17.

27 Frederick Pike, The United States and the Andean Republics, 231.

${ }^{28}$ Peter Flindell Klarén, Peru: Society and Nationhood in the Andes, 275.

${ }^{29}$ Klarén, Peru: Society and Nationhood in the Andes, 298. 
1945. Despite the similar politics leanings, APRA and the Peruvian military never trusted each other again, and the armed forces would do whatever it could to prevent the party from gaining power. As a response to military repression, APRA moved towards the center of the political spectrum as the twentieth century progressed. This shift occurred as the APRA party hoped to become a more legitimate party that would not be suppressed by the Peruvian government.

The Odría dictatorship is an important stepping-stone from the political world of pre-WWII and the turn towards reform to prevent the spread of communism. Peru immediately began to cultivate as much foreign investment as possible and obtained over eight hundred million dollars of investment by $1956 .{ }^{30}$ Three hundred million came from the United States alone. ${ }^{31}$ Although Odría cultivated the support from the extreme right, many workers gave their support as he attempted to model his rule on the populism of Juan Perón in Argentina. He did this by providing land, services, and public works for the urban poor who lived in shantytowns circling Lima. The end of the war also brought an economic mission similar to the Kemmerer one from the 1920s. The Klein mission of 1949 similarly called for a balanced budget, broader tax structure, and an end of the subsidization of certain goods, but differed by arguing that Peru needed to keep its foreign affairs in the western hemisphere since Odría had been moving towards closer relations with Japan in the late 1940s. Despite the acceptance of these economic recommendations, Peru would not completely acquiesce to complete support for U.S. foreign policy of economic liberalization and economic orientation towards the United States. Odría

30 John V. Kofas, Foreign Debt and Underdevelopment: U.S.-Peruvian Economic Relations. (Lanham: University Press of America, 1996),119.

${ }^{31}$ Peter Flindell Klarén, Peru: Society and Nationhood in the Andes, 300. 
installed communists as labor leaders, but encouraged capital from the United States as well as from European nations. ${ }^{32}$

The most important military connection between Peru and the United States during Odría's eight-year tenure occurred in 1952 with the Mutual Assistance Pact. This pact committed the United States and Peru to share equipment, services, information, and military assistance with each other to defend the Western Hemisphere. ${ }^{33}$ Military aid rose astronomically from 100,000 dollars in 1956 to 59.3 million by 1965 . A U.S. army mission arrived in 1956 as part of this funding. The United States gave these funds partially to implement infrastructure improvements to promote modernization. However, this modernization often came at the expense of workers and the poor. In 1953, the Peruvian dictator brutally suppressed the strikes of trade unionists, textile and sugar workers. Labor of all kinds was treated more favorably after the strikes, but only when the workers were willing to work within the Peruvian government's purview. The Mutual Assistance Pact strengthened governments in Latin America, but many Latin Americans saw the pact as a continued example of the U.S. meddling in their nations.

In 1956 under pressure from elite Peruvians, Odría decided to allow free elections, which presented a new path for Peruvians. Fernando Belaúnde Terry, representing the center left Popular Action Party, Manuel Prado representing the newly created Pradist Democratic Party, and the former dictator ran as head of the National Odriista Union. Prado won the election by gaining the support of the left for his promise to legalize the APRA party once in office..$^{34}$ Prado's most important contribution, or subtraction appropriately, to

32 Frederick Pike, The United States and the Andean Republics, 296.

${ }^{33}$ Daniel Sharp, U.S. Foreign Policy and Peru, 38.

${ }^{34}$ Peter Flindell Klarén. Peru: Society and Nationhood in the Andes, 307. 
the US-Peruvian relationship consisted of a concerted effort to move his nation away from economic dependence on North America. Peru's 1957 recession showed government officials that diversification could help Peru weather the economic storm. However, Prado remained a product of the upper classes so his policies continued to help the bourgeoisie with some small concessions to the working class due to his alliance with APRA.

The intelligentsia reacted with anger over these changes, and the famous 1958 Nixon tour of Latin America provided an important outlet for Latin American frustration with the United States. Widespread frustration stemmed from U.S. support of dictatorial regimes and economic inequality. Nixon's visit to Peru in May 1958 resulted in a promise of loans for development that Peruvians desired, but the visit went downhill. Demonstrators burned the American flag wreath left by the statue of revolutionary war hero José de San Martín, college students from the Catholic University of Lima refused to meet Nixon, and representatives from the Chamber of Congress criticized U.S. economic policies. ${ }^{35}$ The South American tour turned violent during Nixon's last stop, Venezuela, after a group of angry Venezuelan students in Caracas almost overturned the vice-president's car. This event began to show the United States that its pre-World War II foreign policy aims of merely making a stable business situation for Latin America would need to change, but it would take two significant events for a true reevaluation.

\section{Cuba, the United States, and Peru}

The first dramatic shift in Cold War politics for Latin American came with the success of Castro in the Cuban Revolution, and the second came with the election of John F. Kennedy as President of the United States. The Cuban Revolution showed that a

35 Jon V. Kofas, Foreign Debt and Underdevelopment: U.S.-Peruvian Economic Relations, 165. 
determined number of rural insurgents could overthrow a Latin American government and cultivate popular support. Peru's situation mirrored the Cuban environment in several important ways. The peasantry remained in a feudal economic system in which only thirty percent of the Indians of the Sierra, Peru's inner highland, spoke Spanish. ${ }^{36}$ Population growth forced many of these people into the cities, and in just one example, the urban poor drove the population of the city of Huancayo from 27,000 in 1940 to 67,000 in 1961 . The population growth and the decline for Peruvian goods due to the end of World War Two and the Korean War as well as regional famines created a new drive for peasants to leave the countryside.

The modern peasant movement began in the state of Pasco when the Cerro de Pasco Copper Corporation ended a program to give farmers part time employment in the mines in 1958. These peasants, also known as comuneros, took over hacienda land in response to their inability to survive. These peasant movements reached their apex with the military suppression and the deaths of ten comuneros in 1962. The government's actions drove the movement deeper into the jungle for future radicalization, and began the military's leftleaning political consciousness. ${ }^{37}$ Soldiers saw the intense poverty of the countryside, and the incredible despair sustained by an unequal system. The implications of the poverty frightened both the military and the United States, who feared that the mal-distribution of wealth would increase the attraction of communism.

US-Peruvian Relations Come into Conflict: insurgencies and coups

36 Peter Flindell Klarén, Peru: Society and Nationhood in the Andes, 312.

${ }^{37}$ John V. Kofas, Foreign Debt and Underdevelopment: U.S.-Peruvian Economic Relations, 192. 
President Kennedy and the State Department initiated the Alliance for Progress in an effort to reduce Latin Americans' attraction to communism from becoming the dominant political ideology. The Alliance for Progress was a U.S. government program that provided anti-poverty aid to Latin American nations in an attempt to stymie communism's appeal to the poor. Kennedy feared that lack of action could create a breeding ground for more Castro inspired leaders. The program also gave a large amount of aid to foster leaders who supported liberal democracies, and increase the number of self-sufficient citizens who respected both government and business. However, this self-sufficiency threatened the power Latin American establishments enjoyed having over their citizens. Seventy two million dollars was provided to Peru over the course of the 1960s for modernization projects, but this money failed to correct the real problem of land inequality. Military assistance came through the Alliance for Progress as well, but with a shift from hemispheric defense to focusing on maintaining stability within each nation, a policy known as Internal Security Doctrine. The implementation of the Internal Security doctrine meant that Latin American militaries would not only need to cut their spending, but simultaneously focus on preventing uprisings by dissident political forces. However, Peru lost direct Alliance for Progress funding over an ongoing dispute with a North American oil company (IPC) over subsoil rights. The consideration of expropriation to settle the conflict violated one of the conditions for funding. Peru's military felt that they were being defanged and betrayed by their traditional ally. For the Peruvian people, IPC was the symbol of foreign oppression and arrogance as this North American company believed itself to be entitled to Peruvian resources. The military wished to be an important player in the domestic scene rather than an enforcer of the status quo. 
The uproar over the suppression of the peasant movement led to a divisive 1962 presidential election. The new and more moderate APRA party nominated Victor Haya de la Torre, Belaúnde returned as candidate for Popular Action, and Odría came back as head of his own party. The United States supported Haya because of his strident anti-communism. Haya remarked after his visit to the Soviet Union that communism managed to improve lives only marginally and without liberty while the APRA would improve lives with both liberty and bread for all. The success of the APRA campaign deeply unsettled the military and when it appeared that Haya had beaten Belaúnde, the military deposed the government to prevent the left leaning party from gaining power.

In 1962, This plan was disrupted by General Ricardo Godoy’s military coup. The 1962 election ended with an alliance between the Odría and APRA that the military could not accept. Godoy overthrew the government to prevent APRA influence in the government. The United States severed relations immediately following the nondemocratic government takeover. This meant Peru immediately lost of both military and non-military aid. The State Department sent a telegram to the embassy in Peru stating, “The United States Government...feels Junta government must understand that developments in Peru have created difficult problem for USG involving military assistance programs both for Peru in particular and for LA in general. ... At some appropriate timeperhaps early next year- we would be prepared to review, in light of developments, subject of military aid level for remainder of interim period prior return normal situation."38 The United States attempted to use military aid as a stick to promote a future free election, but the coldness of the Organization of American States to this process forced the United States

38 U.S. Department of State, “Outgoing Telegram to the embassy in Peru, September 10, 1962. 
to resume diplomatic relations with Peru. Attempting to use the cutoff of military aid as influence would continue to be a favored and important tactic used by the United States even past the institutional revolution of 1968.

\section{Nationalism and Marxism}

Another important aspect of Peruvian foreign policy and other Latin American nations included the embrace of nationalist ideology. Peru realized that nationalism provided an important way to retain power through its simple repudiation of all matters foreign and communist. ${ }^{39}$ The United States was shocked that its repudiation of the coup mattered little to the Peruvian public. Godoy's military government would also become an early inspiration for the institutional revolution and left leaning reforms in 1968. Godoy and his officers embarked on an agrarian reform program that promised land for over 14,000 peasants, but the plan failed due to the short lifespan of the dictatorship. ${ }^{40}$ The military allowed elections the next year as they had promised to do at the onset of their coup. Nationalism increasingly played an important role in marshaling support against the United States in Latin America.

In 1963, The election of Fernando Belaúnde to the Peruvian presidency brought a continued effort toward reform, but two years later a Marxist uprising by the Movement of the Revolution, MIR or Movimiento de Izquierda Revolucionaria, and the National Liberation Army, ELN or Ejército Liberación nacional, drove a wedge between the president and the military. These revolutionaries hoped to use Che Guevera's Foco Theory to inspire the

${ }^{39}$ Stephen Rabe, The Most Dangerous Area in the World: John F. Kennedy Confronts Communism in Latin Americ. (Chapel Hill: University of North Carolina Press, 1999), 121. ${ }^{40}$ Peter Flindell Klarén, Peru: Society and Nationhood in the Andes, 320. 
peasants to join the revolt against the status quo. ${ }^{41}$ However, the armed forces quickly assassinated the leader of the MIR and cleaned up the rest of the leftist movement by the January of the following year. The United States refused to supply napalm for the counterinsurgency campaign in 1965, but it did grant almost $\$ 3$ million dollars to assist in the operation. ${ }^{42}$

This refusal proved to many in the Peruvian military that the United States was not the friend that it so often claimed to be. The communist uprising turned a large part of the Peruvian military against the United States due to the lack of on the ground support, and the relative slowness and disinterest shown by Belaúnde at the beginning of the conflict. U.S. labor leaders attempted to rectify the inequalities by helping the APRA party unionize peasants. ${ }^{43}$ Since the 1920 s, the military had viewed the APRA party as a threat to Peruvian society. All of these actions deeply angered the top brass of the Peruvian military. Perhaps the most important result of the conflict remains the indelible impression of poverty that the Peruvian military encountered during the counter-insurgency. Many officers began to see the incredible inequality not far from that capital, and they began to understand why the message of communism would appeal to the destitute farmers. ${ }^{44}$

Belaúnde's reform, and conflict with the United States

Belaúnde's presidency consisted of several important projects to reform Peru's society and economy. Agricultural input decreased dramatically in the first seven years of

${ }^{41}$ Che Guevara's guide to guerilla warfare argued that a small band of guerillas could instigate a revolution by striking against an unpopular regime and then cultivating a wide following.

42 Richard Walter, Peru and the United States, 1960-1975, 77.

${ }^{43}$ Frederick Pike, The United States and the Andean Republics: Peru, Bolivia, Ecuador, 330.

${ }^{44}$ Ibid., 78. 
the 1960s as investment moved towards the burgeoning industrial section. ${ }^{45}$ Agrarian reform began with the president's tour of the Sierra by truck and horse to speak with peasants, and welcome them into a popular cooperation. ${ }^{46}$ Unluckily for the campesinos, Belaúnde believed that the first step for the agrarian reform would be to construct a massive road along the Ceja De la Selva or Eyebrow of the Jungle to connect the Amazon rain forest to the rest of Peru. The peasants acted before agricultural reforms could be created, and almost 400 haciendas owners lost their lands from 1963 to 1964 . The government reacted by sending in special troops to wrest control from peasants, and over 300 died before the 1964 agrarian bill was signed into law. This bill based redistribution upon productivity only with land over 150 hectares designated to be split up, but only for farms not considered to be highly productive or held by foreign citizens. However, the law never went into full effect and only four percent of redistributed land became the property of one percent of rural families.

The deterioration of US-Peruvian relations would only truly begin in 1966. The government of Fernando Belaúnde and the Peruvian military became upset over the declining quality of American officers sent to help train their soldiers. This was due to growing American involvement in the Vietnam War, which caused American military aid to decline precipitously. The United States reduced the number of advisors from sixty six in 1966 to nineteen just two years later. In a response to the falling military aid, Belaúnde's government purchased 12 French Mirage III jets, 16 British Canberra bombers, a number of

45 Klarén, Peru: Society and Nationhood in the Andes, 332.

${ }^{46}$ Jaymie Heilman, Before the Shining Path: Politics in Rural Ayacucho, 1895-1980, (Palo Alto: Stanford University Press, 2010), 123. 
U.S. made F-80 and 86 jets, and in 1967 several British cruisers. ${ }^{47}$ The United States generally sold the vast majority of equipment to Peru, but Belaúnde's action marked an important shift. Many Latin American leaders believed that if a military received more weaponry it would be pacified; thus less likely to stage a coup.

The United States gave an offer of Northrop F-5 fighter jets to try to stop the sale of the Mirage jets, but disagreements over debt payments turned the Peruvians towards the French jets. ${ }^{48}$ This exact situation was to plague the U.S.-Peruvian relationship. The final nail in the coffin of the Belaúnde administration would not be a military matter, but its failure in 1968 in resolving a decades long conflict with the New Jersey based International Petroleum Company.

Natural Resources and foreign exploitation of them were always an aspect of Peru's history. Spain's conquest of the New World began Peru's reliance on the extraction of natural resources, particularly silver, but reliance on the earnings from exports as well as foreign influence continued on its domestic economy long after independence. For Example, the International Petroleum Company, IPC, based in New Jersey, began operations in Peru in 1914, and bought the La Brea and Pariñas oilfields in 1924 from a British company. ${ }^{49}$ IPC continually claimed that it had special privileges of natural resources that allowed the company to control the subsoil rights. ${ }^{50}$ The Peruvian government attempted in multiple instances to charge higher taxes, but always backed off when the International Petroleum Company pressured the government with halting gasoline supplies. The biggest problem as neither party could prove who actually owned

${ }^{47}$ Sharp, U.S. Foreign Policy and Peru, 18.

48 Walter, Peru and the United States, 1960-75, 108.

${ }^{49}$ Sharp, U.S. Foreign Policy and Peru, 247.

${ }^{50}$ Clayton, Peru and the United States: The Condor and the Eagle, 92. 
the subsoil rights. ${ }^{51}$ Each decade created more and more Peruvian hostility and nationalism towards the foreign company.

The U.S. became involved even though the Standard Oil Company Peruvian subsidiary was registered as a Canadian company. Still it asked for protection from the United States. The oil company controlled of over 60 percent of Peru's oil by the end of the 1920s, and loaned Peru over 450,000 dollars in the beginning of the Great Depression. Politicians and newspapers loved to decry the power of the IPC especially attacking the company for failing to pay enough taxes and failing to treat Peru with respect. From the beginning, many called for the nationalization of the International Petroleum Company as it controlled the majority of Peru's oil, but only in the 1960s would the call be taken seriously.

The movement to nationalize IPC heated up in 1965 as Belaúnde promise to collect back taxes, and settle ownership came to a head as the Popular Action party decided to endorse nationalization with compensation as a solution. ${ }^{52}$ The United States had recently been forced to temporarily end economic aid due to the tuna boat controversy, and the State Department informed the Peruvian president that nationalization was unacceptable. This decision as well as IPC's refusal to come to a resolution over oil prices and subsoil rights continued to hurt the president. The problems with American tuna boats and funding came from seizures in 1966 and early 1967, but with an extremely important diplomatic development. Republican Congressman Thomas Pelly from Washington state used the opportunity to introduce an amendment to the Foreign Military Sales Act of 1968. The Pelly Amendment prevented the United States from selling any military hardware or

${ }^{51}$ Clayton, Peru and the United States, 106.

${ }^{52}$ Richard Walter, Peru and the United States, 1960-75, 81. 
even service to a foreign nation that seized American fishing vessels..$^{53}$ Once again this amendment would deeply complicate the US-Peruvian relationship, and make diplomacy far harder for the State Department.

January $27^{\text {th }}$ of 1968 marks an important turning point as Belaúnde issued a decree that forced negotiations between IPC and the Peruvian state oil company, Empresa Petrolera Fiscal. IPC executives decided that speaking with the oil company would be better than negotiation directly with the government. These talks extended into July with the help of U.S. Ambassador John Wesley Jones when IPC decided to transfer La Brea y Pariñas and its subsoil rights, which the company had owned since the 1920s, to Peru in exchange for the government dropping its back taxes claims. ${ }^{54}$ The agreement signed in August of 1968 became known as the Act of Talara with the price of oil remaining high for IPC, and allowing workers to remain employed. The United States sighed with relief, as they believed this constant problem had finally been resolved, but the nation did so prematurely. The actual contract of the Act appeared to be missing the crucial page eleven that returned control of the oilfields to Peru, and the nationalist segment of Peruvian society decided that the oil's company supposed treachery and the incompetence of Belaúnde's government could no longer be tolerated. The military knew that the APRA party could easily come to power in the upcoming elections with the increased unpopularity of the Belaúnde regime. A military coup under the leadership of General Juan Velasco Alvarado deposed Belaúnde on Oct $3^{\text {rd }} 1968$, and seized the oilfields. The United States, distressed and surprised, cut off relations. 1968 was not a typical year for U.S.Peruvian relations.

${ }_{53}$ Walter, Peru and the United States, 96.

${ }^{54}$ Walter, Peru and the United States, 128. 
Peru and the United States maintained an unusually beneficial relationship from the beginning of nationhood. Peru happily accepted military support after each of the great global conflicts during the $20^{\text {th }}$ century. The Cold War brought the a sizable number of US sponsored coups to depose or attempt to depose left leaning governments, such as in Guatemala, Cuba, Dominican Republic, and Chile, but Peru managed to avoid the worst effects of anti-communism from its powerful northern ally. However, political differences beginning in the 1960 s came to a head with the 1968 Peruvian Revolution. The accompanying accommodation by the United States was due in great part to the traditional military connection, and the deep respect and trust that the United States felt towards the Peruvian military. Velasco's "Revolution from above" would test the relationship in a way never seen between the two nations. 
Chapter 3

The Institutional Revolution in Peru 1968-1972 and the U.S. Response

\section{Introduction}

October $3^{\text {rd }} 1968$ 's great event began with a flurry of telephone calls, and ended with the exile of the Peruvian president, Belaúnde, to Argentina. Juan Velasco's rise to power officially began the Peruvian Revolution (1968-1975). The Peruvian Revolution caught the Central Intelligence Agency, President Belaúnde, and the world off guard. The Peruvian government's actions over the next few years continued to surprise the United States. Velasco unleashed revolutionary changes in Peru. Five main events marked Peru's turn towards a more independent foreign policy that eventually included the purchase of large quantities of Soviet weaponry. First, The Plan Inca agrarian reform in June 1969 ushered in a period of expropriation, and challenges to the Peruvian oligarchy. Second, the formation of the Andean Pact in May of the same year threatened to construct a regional alliance that could destroy the traditional hegemony of the United States in Latin America. Third was a devastating earthquake in May 1970 that impacted both the United States' relationship with Peru as well as the development of the Soviet-Peruvian relations. Fourth in 1972, the consistent seizure of US tuna boats sparked reaction by infuriated congressmen and businessmen into action largely, but Peru's cooperation in the drug war brought a sizable cooling to the U.S.-Peruvian relationship. In addition to the land reform and tuna-boat controversy, Peru nationalized industries owned by U.S. companies. The fifth event occurred in Chile rather than Peru and was one of most important events in Latin America during the 1970s. Socialist Salvador Allende was elected president in September 
1970 leading President Nixon and National Security Advisor Henry Kissinger to begin to accept, with some reluctance, that Latin America had emerged as one of the most important areas in global politics to the jubilation of some, and the horror of many. These events highlight both the attempts of Peru to change its position in the region, the concurrent problems that made the U.S.-Peruvian relationship difficult to manage, and the earthquake that cooled the relationship but brought the Soviet Union into Peru. The United States needed to retain Peru as an ally to combat communism in South America and to retain access to Peru's natural resources. Peru wanted to become more independent economically from the United States, and embark on a mission of modernization. These two visions ran headlong into one another with both nations feeling that they not accommodate one another's demands or cut ties.

\section{From Belaúnde to Velasco}

The deterioration of U.S. -Peruvian relations in the 1960s is due to a few important moments. The ever-continuous controversy over U.S. tuna fisherman fishing in Peruvian waters stirred deep feelings of nationalism among the Peruvian people against the United States. The guerilla uprising in 1965, and the U.S. army's refusal to supply napalm to Peru greatly damaged its relationship with the Peruvian army. Finally, the US refusal to sell supersonic jets to Peru showed many in Peru that dependence on the United States would need to be gradually curtailed. Despite these ruptures, the United States would continue to try to mend the relationship. Why would Peru get this special treatment and other left leaning nations in Latin America would not? 
Despite Peru's anti-U.S. and anti-free market policies, US-Peruvian relations remained relatively cordial in the Velasco era. The strain would be great, but both nations worked desperately to keep events from moving too far from the pre-1960s amiability. Traditionally, the two bedrock policies of the United States towards Latin America were that the governments in the region needed to promote a friendly business climate for foreign private-sector capital; and secondly Latin American governments needed to keep Soviet influence out. Left-of-center nations such as Chile and Guatemala received a cold shoulder when attempting to change their societies, but Velasco benefited from the fact that the U.S. allowed greater flexibility for Peru's relationship with the Soviet Union. The result of Peru purchasing Soviet arms was that the United States realized that accommodation was the only coherent option for the Latin American nation. The answer for this outcome is a combination of historical ties, exceptional diplomacy on the part of the Peruvians, the firm non-Marxism of the Peruvian Revolution, minimal ties to Cuba and the USSR, and compensation for expropriated U.S. companies. The lack of another feasible option, such as finding dissident generals to stage a coup, also played a pivotal role.

\section{Velasco: background}

Juan Velasco Alvarado grew up in relative poverty in northern Peru but joined the army when he was 19 to escape his former life. ${ }^{55}$ He was accepted to the Chorillos Military School, which was modeled on American military academies and gained attention for his performance and personal charisma. In 1965, Velasco became chief of staff of the army, and discovered the intransigence of the Peruvian congress to change and its slowness in

55 Abraham Lowenthal and Cynthia McClintock, The Peruvian Experiment Reconsidered (Guildford: Princeton University Press, 1983), 215. 
fighting leftist guerillas. The general despised the International Petroleum Company's control over so much of the nation's resources. Ultimately, the company's refusal to honor the Act of Talara, the act that would require of I.P.C. to turn over the La Brea oilfields to Peru in exchange for concessions, proved to be too much for Velasco, and the generals and colonels around him.

Velasco's greatest influence came from neither the United States nor the Latin American leftist tradition. The mid-nineteenth century Peruvian president Ramón Castilla created the template for the Peruvian Revolution. ${ }^{56}$ Castilla's military rule was marked by modernization of the armed forces, laws, and a respect for constitutions. This president wielded power through a series of decrees, which included the abolition of slavery. Castilla's core beliefs stemmed from Peruvian nationalism, and he initiated a defense treaty with Chile and Bolivia to protect South America from an aggressive Spain. Velasco remained a committed nationalist and anti-communist all of his life, and defined his beliefs and goals to his friend Meza Cuadra, "Power spreads its tentacles from above. Everywhere the rich pull the strings. The big companies call the shots." He continued, "We need to press for reform in Peru, to regain its sovereignty, especially in relation to the United States." 57 The other important influencer on Velasco was Marxist philosopher José Mariátegui's seminal work Seven Interpretive Essays on Peruvian Reality, which expressed the view that drawing on the Incan past could reform Peruvian society.

${ }^{56}$ Dirk Kruijt, Revolution by Decree: Peru, 1968-1975, 11.

${ }^{57}$ Kruijt, Revolution by Decree, 73. 
The Revolution from Above Begins

On Velasco's first day in office, he stated, "The Revolutionary Government, at one with the aspiration of the Peruvian people calls on them to struggle, together with the armed forces, to attain authentic social justice, dynamic national development, and the reestablishment of the moral values which alone can guarantee the achievement of the highest destiny for our fatherland." ${ }^{58}$ His closing remark on October $3^{\text {rd }}$ left the United States with several important questions. Could the United States expect more action against American businesses, and would this be emulated by other Latin American nations? No one could be certain if the statement reflected the true beliefs of Peru's new leaders, but the military wasted no time in showing that their words would lead to action. The new government immediately declared the Act of Talara to be void, and the United States responded by suspending relations the same day. ${ }^{59}$ This simply meant that the United States would review the situation while the embassy in Lima continued to operate. The Velasco regime assured the three largest mining companies in Peru that IPC's expropriation was not a threat to other foreign companies that followed Peru's laws. ${ }^{60}$ (Discussed Below)

\section{Oil Expropriation Roils US-Peruvian Relations}

Five days after the United States suspended relations with Peru, Velasco assembled a few hundred officers in the Presidential Palace to announce that the military would take

\footnotetext{
58 North, Liisa and Tanya Korovkin, The Peruvian Revolution and the Officers in Power: 19671976 (Montreal, McGill University, 1981), 44.

${ }^{59}$ Richard Walter, Peru and the United States, 1960-1975, 145.

60 "Peruvian Seizure of IPC Assets" Central Intelligence Bureau, CIA-RDP7803061A000400020009-8 [CIA CREST, CIA Records Search Tool, System, National Archives and Records Administration, Archives II, College Park, MD] (Hereafter Crest, NARA II)
} 
over the oilfields of La Brea y Pariñas. The decree noted that foreign investment would still be welcome in Peru, but only if they followed the law. ${ }^{61}$ While IPC reacted with indignation, the Peruvian populace jubilantly celebrated the long desired victory over the ultimate symbol of U.S. oppression in Peru. October $9^{\text {th }}$ brought the expropriation of the refinery in Talara and continued dodging by Peru on the question of compensation based upon the belief that IPC owned Peru hundreds of millions in back taxes. ${ }^{62}$ Nixon's inauguration in January 1969 changed very little in policy towards Peru as Nixon focused on resolving the conflict in Southeast Asia.

From Bilateral Relations to Regionalism

Although the State Department wanted time to think about the situation, members of Congress and the oil industry rushed to the State Department to ask that the Hickenlooper Amendment, that required aid and funding to be cut off from any nation that expropriates U.S. businesses without compensation, to be invoked. The State Department hated the Hickenlooper Amendment because it limited diplomatic flexibility and removed the important bargaining chip of military aid completely. The popularity of the military government among the Peruvian people, and the reluctance of the Secretary of State, Dean Rusk, to use the amendment gave Peru time to prevent relations from further deteriorating. President Lyndon B. Johnson and Ambassador Jones decided to recognize the junta for fear that the United States would lose influence over the revolutionary government. ${ }^{63}$

\footnotetext{
61 Richard Walter, Peru and the United States, 1968-1975, 148.

62 Lawrence Clayton, Peru and the United States: The Condor and the Eagle, 247.

63 Richard Walter, Peru and the United States, 1960-75, 154.
} 
Congress and State Department continued to spar over the Hickenlooper

Amendment during Velasco's seven-year rule, and the United States continued to resist punitive actions against Peru for fear of losing influence. In a memorandum from the State Department to the Assistant for National Secretary Affairs, Henry Kissinger, the agency coolly gauged effectiveness of the amendment as,

"Suspension of aid and the sugar quota will have a serious adverse impact on the Peruvian economy, probably lead to reprisals against other US investments, alienate the Peruvian people and stimulate an actively hostile policy toward the US, perhaps push Peru further toward economic and diplomatic relations with the Soviet bloc, and damage USPeruvian relations for a long time to come-all with repercussions harmful to our interest elsewhere in the hemisphere" 64

The Revolutionary government of Peru finally received recognition on October 25 1968, but the relationship remained rocky until 1975. In July 1969, arms sales were reinstated as a sign of good faith but discontinued once again in 1972 with the return of tuna boat seizures. ${ }^{65}$

Along with the internal politics of Peru, the regional politics of South America formed an important part of the United States reaction to the coup. Brazil proved to be the United States' most important ally in the region after a military coup in $1964 .{ }^{66}$ General and president Emilio Garrastzu Medici stated to Nixon in 1971, "Our position cannot be the same vis-à-vis every international problem- nor is this expected from our frank and loyal friendship- let us, never-the less, endeavor to make our policies converge without requiring

${ }^{64}$ Department of State to Assistant for National Security Affairs, Henry Kissinger, "Memorandum for Dr. Kissinger", January 28, 1969, Foreign Relations of the United States, 1969-1976, Volume E-10, Documents on American Republics, 1969-1972. eds. Douglas Kraft and James Siekmeier (Washington: Government Printing Office, 2009), Document 576. https://history.state.gov/historicaldocuments/frus1969-76ve10/d576

65 Richard Walter, Peru and the United States, 1960-75, 265.

66 Tanya Harmer, Allende's Chile and the Inter-American Cold War (Chapel Hill: University of North Carolina Press, 2011), 22. 
that they coincide in every case."67 General Medici would play an important role in the Augusto Pinochet's Chilean coup in 1973. U.S. foreign policy accepted more deviation from Latin American norms as the Cold War went on due to the need for allies. The fear that communism would infiltrate South America drew vast amounts of money from the United States for reforms with Chile receiving the lion's share. Chile's president, Eduardo Frei, received over \$3.2 million dollars from the Central Intelligence Agency to prevent the ascendency of Allende in the 1970 election.

Bolivia's election of two one-term presidents from 1969 to 1971 attracted a similar attention from the United States and Brazil. Bolivia's relationship with the United States moved in a fascinatingly ambivalent way beginning in the early 1950s with Bolivia utilizing fear tactics to force the United States to send economic aid to prevent left wing uprisings or a diplomatic move towards the Soviet bloc. ${ }^{68}$ Despite the large amount of agency in the relationship, Bolivians turned further towards nationalism and left wing dictatorships in response to anger over the decline in American aid after Che Guevara's disastrous 1967 mission in Bolivia. The Bolivian junta nationalized Gulf Oil in October 1969, only a year after the Peruvians expropriated IPC holdings, and the United States responded by dramatically cutting aid. ${ }^{9}$ However, Bolivian and U.S. leaders both disliked the response and an agreement to pay compensation occurred almost a year later. Compensation helped to fix the relationship between Bolivia and the United States and demonstrated that respect for private property was one of the principal values of U.S. foreign policy.

\footnotetext{
${ }^{67}$ Samuel Baily, The United States and the Development of South America, 1945-1975 (New York: Franklin Watts), 164. ${ }^{68}$ James Siekmeier, The Bolivian Revolution and the United States, 1952 to the Present (University Park: Pennsylvania State University Press, 2011), 5.

${ }^{69}$ James Siekmeier, The Bolivian Revolution and the United States, 127.
} 
The seizures of tuna boats, often referred to as the Tuna Boat War, continued to play an important role in regional politics for Latin America. Ecuador, Chile and Peru shared a hatred for the American fishermen who they believed encroached upon their rights to the sea's natural resources. 1952 brought the Declaration of Santiago in which all three nations asserted a two hundred mile limit from the coast to foreign fisherman. ${ }^{70}$ The United States refused to recognize this declaration due in part to desire to defend Taiwan from China, and the setting for the Tuna Wars was established. International law guarantees every state three miles of sea, but the general trend for nations is to protect twelve miles. ${ }^{71}$ Peru, Ecuador, and Chile all claimed in excess of 200 nautical miles to protect their fishing industries in the 1960s and 1970s. The Pelly Amendment, which required the United States to pay the fines of fishermen by deducting aid allocated to the host nation, and requiring military sales to be halted, came from this longstanding issue. Military ships sold to Ecuador and Peru by the United States seized U.S. commercial vessels. This was an outrage to many in the North American nation.

Ecuador's relatively left leaning president Juan Velasco Ibarra ramped up the tuna seizures in 1971 just as Peru's Velasco did, but Ibarra faced an end to military sales and responded with the expulsion of the U.S. military mission. In 1969, as a result of its seizure, Peru briefly lost military funding, and responded by expelling its U.S. military mission. ${ }^{72}$ Velasco angrily expelled the U.S. military mission in retaliation even though he would have preferred the troops to stay, but his nationalist beliefs forced him to do something against

\footnotetext{
70 Ronn Pineo, Ecuador and the United States: Useful Strangers, 175.

71 Encyclopædia Britannica Online. http://www.britannica.com/topic/territorial-waters. Date Accessed June 20th, 2016

72 Richard Walter. Peru and the United States, 1960-75, 173.
} 
the injustices against Peru. ${ }^{73}$ Public opinion in Peru sided heavily towards Velasco, and the United States leadership realized that sanctions would only continue to improve the president's political position.

\section{Peru attempts to smooth US-Peruvian Relations}

Peru's desire to solve the tuna crisis through mediation came through a proposed meeting between Ecuador, Peru, and Chile. This meeting proved to American officials that military sales should be resumed on July $4^{\text {th }} 1969.7^{74}$ The tuna controversies in 1969 proved to the United States that punitive measures would not do well in dealing with Velasco, but Peru's willingness to work with the United States to mediate disputes helped move both nations towards settlement. American foreign policy would have to be more conciliatory towards the Latin American nation as the military government would merely play that nationalism card or go elsewhere if they believed they were receiving a raw deal. On the first day of the Peruvian Revolution, General Mercado Jarrín stepped into the position of Foreign Minister with a plan to disrupt Latin American politics by intentionally manipulating the United States. The General believed that Peru could make up for its weakness by establishing links with Yugoslavia, Poland, and the Soviet Union to force the "Colossus of the North" to make concessions to his nation. ${ }^{75}$ Training at Fort Leavenworth,

\footnotetext{
${ }^{73}$ Central Intelligence Bulletin, May 31 1 st 1969 , CIA-RDP79T00975A01380009002-8, [CIA CREST System, National Archives and Records Administration, Archives II, College Park, MD]

${ }^{74}$ Foreign Relations of the United States, 1969-1976, Volume E-10, Documents on American Republics, 1969-1972, eds, Douglas Kraft and James Siekmeier (Washington: Government Printing Office, 2009), Document 606. https://history.state.gov/historicaldocuments/frus1969-76ve10/d606 Accessed March 19th 2016.

${ }^{75}$ Richard Walter, Peru and the United States, 1960-1975, 157.
} 
and the Inter-American Defense College in Washington D.C. made Mercado the perfect candidate for foreign minister.

Although appointed by Velasco's predecessor, Ambassador to the US, Fernando Berckemeyer, held opposing conservative views to the government that he served.

Berckemeyer spoke English fluently, was married to a North American woman, and had spent over eight years as ambassador to the United States. He also promised to be the perfect candidate. Velasco decided that Berckemeyer would remain the ambassador to the United States as a diplomatic tactic. The ambassador could play the role of a captive to the left leaning government in order to convince the Americans that a further shift to the left would transpire if U.S. officials did not follow the ambassador's advice. These two foreign policy members, Mercado and Berckemeyer, would play an integral role in advancing Velasco's diplomatic goals.

\section{The Revolution's Reforms}

On June 24 1969, Velasco reached into the homes of Peruvians through television to proclaim that the elites who owned the land would no longer feed off their poverty, by promising comprehensive land reform. ${ }^{76}$ Velasco's goals for the land reform had far more comprehensive objectives than the moderate attempt at land reform under Belaúnde's presidency. Through agrarian reform, he hoped to correct the incredible inequities in Peruvian society and prevent impoverished peasants from turning to communist ideology. Agrarian reform played an important role in national security to the minds of the military leaders as disenfranchised peasants could easily turn towards communism or the APRA

76 Orin Starn, ed. 2. The Peru Reader (Durham: Duke University Press, 2005), 284. 
party. Seven hundred hacienda owners ruled over half of the best land and employed twenty percent of all rural families. ${ }^{77}$ These hacienda owners refused to build schools for their employees and immediately replaced workers at the hint of unionization. Indeed the land of the powerful and American affiliated company Casa Grace or Grace Corporation, which controlled over fifty percent of sugar production, was expropriated the day after the Plan Inca announcement ended the corporation's long history. Land exemptions from the reform varied from area to area, but peasants and community members could protest an exemption if they believed that the land could be put to a better communal use. ${ }^{78}$ Under Velasco, water became a national resource to be protected by the government thereby eliminating hacienda control of streams and rivers. The revolutionary government hoped that the reform would destroy the power of the landed aristocracy, improve the lives of peasants, remove the threat of communism, and increase the productivity of Peru's agricultural yield. ${ }^{79}$ The land given to the peasants would be split up into two distinct types of cooperatives. Agrarian Production Cooperatives focused on the large coastal estates and the Agrarian Social Interest Societies would take control of the best sierra land properties. Hacienda owners would be compensated with government bonds.

These cooperatives would be based upon gender mutualism (men and women in the farm working closely together) of the Incan past, but the government's vision of gender did not match the Quechua women's ideas. Campesina women, women from the countryside, viewed their place as being in the field with their men. However the cooperatives, run by

\footnotetext{
77 Maria R. Shaleth, "Land Reform Under Military: Agrarian Reform in Peru, 1969-78" Economic and Political Weekly Vol. 26, No. 30 (July 27, 1991), 83.

${ }^{78}$ Cynthia McClintock, Peasant Cooperatives and Political Change in Peru (Princeton: Princeton University Press, 1981), 73.

${ }^{79}$ Peter Flindell Klarén, Peru: Society and Nationhood in the Andes, 346.
} 
men, thought women should be mostly in the home. ${ }^{80}$ Despite the lack of understanding, the author of When Women Rebel does credit the birth of the women's movement in Peru to the government's actions to try to improve the lives of women.

Plan Inca's consequences continue to be hotly debated into the twenty-first century. Close to 8.5 million hectares of former landlord property was given to workers, which increased their salaries by 25 percent. Coastal workers received far more benefits than their sierra counterparts. The poorest farmers often received no benefits from the reform, and unbounded laborers were exploited by the system. ${ }^{81}$ By the end of 1975 , still only twenty five percent of the rural population enjoyed access to the land. ${ }^{82}$ However, the agrarian reform did lead to an increase in production. Rice production grew dramatically because new lands could now be worked, and mechanization began and improved the productivity in cotton and potato production. ${ }^{83}$ Plan Inca did not live past Velasco's reign or succeed in supplanting communism among peasants, but it did endear the Peruvian people to the leaders of the revolution.

Peru's Push for Economic Independence

The next step for Peru in the first years of the military government consisted of intense efforts to garner foreign loans for development. In a shocking move, Peru announced that relations with the Soviet Union had been established on February 1,1969,

${ }^{80}$ Carol Andrea, When Women Rebel: The Rise of Popular Feminism in Peru (Westport: L. Hill Publishing, 1985), xii.

${ }^{81}$ Cynthia McClintock and Abraham F. Lowenthal, The Peruvian Experiment Reconsidered, 265.

82 Peter Flindell Klarén, Peru: Society and Nationhood in the Andes, 348.

${ }^{83}$ Maria R. Shaleth, "Land Reform Under Military: Agrarian Reform in Peru, 1969-78," 91. 
and a trade deal became public knowledge less than three weeks later. ${ }^{84}$ The United States applied non-overt economic pressure to Peru by denying investment and credit from U.S. businesses and international lending groups while avoiding confrontations over the Hickenlooper amendment. ${ }^{85}$ The International Petroleum Company requested for the deferral from the amendment to have time to resolve their issues with the Peruvian government. Kissinger argued that these policies brought Peru closer to the United States since Peru would have to turn back to the United States for economic support, but Peru decided to continue seeking out investment from other nations. Peru hoped that diversification could let relations with Czechoslovakia and Yugoslavia were established close to the same time. In August 1970, the Soviet Union promised a $\$ 30$ million credit to buy Soviet equipment with the promise that Peru would import Soviet manufactured goods. ${ }^{86}$ Mercado visited the United States the next month to ask for help obtaining loans from the World Bank, and contending that the Peruvian Revolution had been far better for business than the 1970 Chilean election. ${ }^{87}$ Peru enjoyed good relations with Chile, but Peru constantly used its relationship the more radical nation as a negotiating tool. Peruvian diplomats continually pointed to the embrace of Marxism to say that the Peruvian revolution was far better as an example to Latin America than its neighbor.

\footnotetext{
${ }^{84}$ Richard Walter, Peru and the United States 1960-75, 172.

${ }^{85}$ President's Assistant for National Security Affairs, Henry Kissinger, to President Nixon, "Memorandum to the President" July 12, 1969, Foreign Relations of the United States, 19691976, Volume E-10 Documents on American Republics, 1969-1972. eds. Douglas Kraft and James Siekmeier (Washington: Government Printing Office, 2009), Document 606. https://history.state.gov/historicaldocuments/frus1969-76ve10/d606 ${ }^{86}$ Richard Walter, Peru and the United States, 1960-75, 235.

87 "Confidential Department of State Memorandum of Conversation" Department of State, September 27, 1971. USNA (1970-1973) (Box 2544, Folder 6), 1-3.
} 
Apart from the Soviet Union, another extra-hemispheric country played an important role in the history of the Andean nations. Japan's history is Peru included a sizable amount of immigration from the island beginning in the late 1800s. May 15, 1961 brought the two countries into most favored nation status, and by 1968, Japan imported more goods to Peru than any other Latin American country. ${ }^{88}$ Peru particularly sought Japanese and as well as European investors as they were more willing to enter into joint ventures and contract agreements. ${ }^{89}$ China also provided a $\$ 42$ million loan, and a promise to buy $\$ 100$ million dollars worth of Peruvian natural resources. ${ }^{90}$ The past importance of Asian nations in the economy of Peru and the large numbers of immigrants from Asia drove Peru to seek closer ties.

Back in the western hemisphere, Fidel Castro offered his support and praised the Peruvian Revolution. However, Velasco rejected Castro's friendship. ${ }^{91}$ In an attempt to maintain at least fairly harmonious relations with the United States, Velasco backpedaled from the compliment and stated that while the coup remained revolutionary it adhered only to nationalism rather than Marxism, socialism, or communism. During this time, Cuba moved away from promoting violence to overthrow capitalism to endorsing candidates or military leaders who wanted to move away from the United States. This shift in tactics helped Cuba become a more respected nation in Latin America. Later in the revolution,

88 Rebecca Tsurumi, The Closed Hand: Images of the Japanese in Modern Peruvian Literature (West Lafayette: Purdue University Press, 2010), 25.

${ }^{89}$ Cynthia McClintock and Abraham F. Lowenthal, The Peruvian Experiment Reconsidered, 155.

${ }^{90}$ Richard Walter, Peru and the United States, 1960-75, 245.

${ }^{91}$ Rebecca Tsurumi, The Closed Hand: Images of the Japanese in Modern Peruvian Literature, 206. 
Peru (partly to placate the Peruvian public and the Third World) worked to improve the international standing of Cuba.

New York Times reporter Jose Yglesias coverage of Peru helped cement Velasco's credentials as an anti-communist, but benevolent and even reformist dictator. Yglesias spent ten days visiting Lima and Trujillo, a city in the North of Peru. The reporter was instantly stunned that there were no slogans, posters, or other propaganda in the capital. He found that the population generally supported the revolution due to anti-foreigner sentiment and the hope for an improvement in their lives. Yglesias then toured Lima with an Aprista ${ }^{92}$ administrator, noting that he "explained that all these events so far" [the nationalizations] were simply a cover for the negotiations now going on with the United States interests for the further development of the mining region." ${ }^{\prime 93}$ This article suggests that the left wing remained hesitant to embrace the revolution. Next, the author met with a political prisoner from the 1965 rebellion. The meeting that occurred completely surprised the author. He simply showed his passport and entered the supposed second worst jail in Peru. He was utterly shocked about the apparent gentle treatment of this rebel compared to the rough treatment his stepson received from police during a sit in at Columbia University. The author then spoke with a Colonel Rodriguez from Velasco's army who denied that the president was creating a country based upon a caudillo, a type of traditional authoritarian leader in Latin America, and stated that negotiations with American copper companies would end with favorable conditions for Peru and businesses. The whole article reflected the author's surprise about the calmness in a country rocked by revolution, and

\footnotetext{
${ }^{92}$ A member of the APRA Party.

${ }^{93}$ Jose Yglesias. "The Reformers in Brass Hats" New York Times, (New York City, NY), December 14, 1969, 58.
} 
the relative freedom given to prisoners and political opposition. The Peruvian ambassador Berckemeyer praised the Yglesias article, and used it to argue that the junta could both improve Peru through minimal control over dissidents while exercising a benevolent leadership for the rest of the population.

The Earthquake and US-Peruvian Relations

On another sunny afternoon, Peruvians, many watching the 1970 soccer World Cup, were forced out of their seats in terror rather than jubilation. An earthquake measuring 7.9 on the Richter scale devastated the city of Chimbote killing over 70,000 people on May $31^{\text {st }}$ 1970.94 The earthquake became an important event in US-Peruvian relations because it allowed the two nations to come together in disaster relief. The tension over tuna boats and expropriation briefly ended as the United States organized and sent disaster relief to the victims of the Ancash Earthquake. In a memorandum to National Security Advisor Kissinger, from CIA director Richard Helms argued that the earthquake did nothing to hurt the political position of Velasco and actually improved basic relations between Peru and the United States. ${ }^{95}$ Richard Walter visited Peru after the earthquake was surprised that despite the large amount of anti-United States propaganda in the form of graffiti and billboards, Peru gratefully accepted aid and was delighted to protect visiting dignitaries from the United States. President Nixon's wife, Pat Nixon, visited the disaster stricken area to help in the relief impressing the Peruvian people, and beginning a close friendship with

\footnotetext{
94 Nathan Clarke, "Revolutionizing the Tragic City: Rebuilding Chimbote, Peru, after the 1970 Earthquake" Journal of Urban History 4 (2015): 95.

95 “Memorandum for Dr. Henry A. Kissinger" June 15 1970, [CIA CREST System, National Archives and Records Administration, Archives II, College Park, MD] RDP79R00967A001400020015-9
} 
President Velasco's wife. ${ }^{96}$ As such, the earthquake served to improve U.S.-Peruvian relations. Yet, the earthquake's most important effect remains the increased influence of the Soviet Union. Despite the lateness of Soviet help, a July CIA memorandum states "The Tardy, but dramatic, Soviet airlift of relief supplies will certainly draw considerable attention in Peru,". ${ }^{97}$ The Soviet Air Force eventually only delivered twenty-one planeloads of supplies of the promised sixty-five, but the aid gave an important foothold for the diplomatic relationship between Peru and the Soviet Union.

Cuba, Peru, the United States, and the Region

By far the most dramatic shift in United States policy in Latin America came in 1970 after the election of Marxist Salvador Allende as President of Chile. National Security Adviser Kissinger and Richard Nixon could not believe that the people of Chile would elect a Marxist to the presidency. They were also very concerned about Allende's close relationship with Castro. Fidel Castro trumpeted Allende's victory by proclaiming the defeat of imperialism in Chile as the banner headline for Cuba's state newspaper..$^{98}$ Allende's prior experience with Cuba included a trip to the Island in the immediate aftermath of the revolution and subsequent trips in 1962, 1967, and 1969, helping Cuban revolutionaries escape from Bolivia and significant campaign contributions from Cuba

\footnotetext{
96 Richard Walter, Peru and the United States, 1960-75, 232.

97 “Intelligence Memorandum- Peru after the Earthquake." July 20 1970, Central Intelligence Agency, [CIA CREST System, National Archives and Records Administration, Archives II, College Park, MD]CIA-RDP85T000875R001100090035-9. 98 Tanya Harmer, Allende's Chile and the Inter-American Cold War, 49.
} 
during the election of 1970. The United States immediately began covert operations known as Track I and subsequently Track II designed to overthrow Allende. ${ }^{99}$

Peruvian officials responded to Allende's Election by stating that their military revolution remained committed to anti-communism, hoping to convince the United States and foreign businesses to invest more in Peru. ${ }^{100}$ Allende's exceptionally positive relationship with Cuba helped the Peruvians portray the revolution to their south as far more radical revolution than theirs. The United States feared that the new Chilean path would lead to either a further drift left in Peru or lead to a military buildup especially since the centennial of the War of the Pacific would occur in less than a decade. Peru lost a large part of its southern provinces during the war, and Peruvians still felt deep animosity about their loss in their war. The Centennial renewed feelings of nationalism that U.S. officials feared could lead to a surprise attack from Peru to recapture their losses. A secret assessment of the inter-American situation from the U.S. embassy in Lima argued that the United States must not allow the situation in Peru to devolve and for the blame to fall upon the United States. ${ }^{101}$ An alliance between the Soviet Union, Chile, Peru, and Cuba would be a diplomatic disaster for the Nixon administration. In 1971, a secret telegram from the embassy in Lima to Washington advocated keeping Chile and Peru from becoming too close or becoming too antagonistic. ${ }^{102}$ An alliance between Chile and Peru could lead to a

99 Tanya Harmer, Allende's Chile and the Inter-American Cold War, 51. Track I along with Track II, conceived by the CIA, included several different plans to oust Allende through peaceful election processes and military repression.

100 Richard Walter, Peru and the United States, 1960-75, 237.

101 Author from the U.S. Embassy Lima, quoted in Ibid., 238.

102 Unknown, 'Secret Air-Gram A-22 from Lima to Washington, January 28, 1971," Box 2544, Folder 4. 
collapse of U.S. influence in South America and protect growing Marxism, while a war could destabilize the entire continent.

Fortunately for South America, Peru and Chile maintained a close but competitive relationship during the Allende years, which was especially remarkable considering their long history of animosity. The Velasco regime worked with Chile on an effort to regain membership for Cuba in the Organization of American States (OAS). The United States efforts against Cuba made many Latin Americans angry, and Peru was happy to exploit their frustration to increase feelings of nationalism among them. These developments frightened the State Department enough that they feared that the entire southern cone of Latin America could unravel.

However, as the decade continued Peru chose to submit a resolution to the Organization of American States for a lifting of sanctions against Cuba. ${ }^{103}$ In 1972, the lifting of sanctions over Cuba put a wedge between Miguel de la Flor, new Peruvian foreign minister and William P. Rogers, new Secretary of State, during de la Flor's first official visit to the United States. The Peruvian administration justified its resolution on Cuba by citing Nixon's establishment of relations with Communist China. ${ }^{104}$ The OAS continued to refuse to reinstate Cuba membership in the group, which caused Peru to normalize relations with Cuba on July 9, 1972. The exact reasons for Peru's defense of Cuba is debatable. The speculations included a diplomatic game of deliberately cooling and warming the U.S. relationship to garner more aid. It might also have been an attempt to become a leader of the non-aligned movement, or simply a domestic politics ploy to extract more nationalist

103 Unknown Author, Central Intelligence Agency, "Notes" December 8, 1971, Central Intelligence Agency, [CIA CREST System, National Archives and Records Administration, Archives II, College Park, MD] RDP79T00975A020600100001-1

104 Richard Walter, Peru and the United States, 1960-75, 253. 
emotions. It is still unclear why Peru would be willing to risk so much by working with Cuba.

There is no doubt that the leaders of Chile and Peru shared very similar political beliefs and followed related paths, but the United States decided to act against Chile rather Peru. Abraham Lowenthal's and Cynthia McClintock's The Peruvian Experiment Reconsidered argues that there was a very specific reason why US policy makers took covert action against Chile to destroy Allende's presidency and not Velasco. This reason was that Peru desired to pay companies back for expropriations of their assets while Chile did not. ${ }^{105}$ Tanya Harmer in Allende's Chile and the Inter-American Cold War agrees. The slightly more moderate policies of Velasco, and the historical closeness of the United States and Peru played an important role in the U.S. government's decision to accommodate Velasco. Compensation played an important role in the survival of Peru in the global community, but Soviet arms forced the United States to approach the nation with more accommodating action.

Peru continued to follow an ambivalent foreign policy towards and against the United States and the more left leaning side of Latin American politics. According to a report in 1971, a meeting in the White House between Kissinger and the Peruvian foreign minister, Edgardo Mercado,

"He (Mercado) repeated that (Peru)it is anti-Communist and he said that Peru viewed with concern the emergence of a Marxist regime in Chile arising from outside influences. Mercado said those who seek power in Latin America by means of guerrilla warfare and terrorism will fail to achieve it, but that coalitions of Leftist forces working through the legal structures were a far greater threat. He said that the Popular Front in

${ }^{105}$ Abraham Lowenthal and Cynthia McClintock, The Peruvian Experiment Reconsidered, 47. 
Chile, if it is successful in socializing a country, will have a powerful demonstration effect in Latin America."106

Velasco expressed this sentiment again in 1972 as he told the US ambassador that Peru and Argentina would need to be concerned about the communist threat to the South. ${ }^{107}$ The State Department and CIA were not fooled by Velasco's finger pointing, but the need for an ally made Peru indispensible. Chile, Peru, Ecuador and Bolivia were all led by left leaning governments in the early 1970s, and the threat of these ideologies spreading deeply troubled the Nixon administration. Peru's government was leftist but anticommunist while Chile's government was leftist and far friendlier to communist nations like Cuba. It was far easier to negotiate with Peru than it was to negotiate with Chile.

One way Peru attempted to reduce its dependence on the U.S. was through forming a regional commercial integration scheme. In 1966, Chile's Eduardo Frei and Peru's Belaunde met to discuss creating an Andean economic bloc that could work together to negotiate with the United States as well as the larger Latin American markets. ${ }^{108}$ Three years later, the charter for the Andean Common Market constituting the nations of Bolivia, Chile, Colombia, Ecuador and Peru all signed the agreement to create a regional marketplace. ${ }^{109}$ The pact required foreign investment in basic industries such as public services to give up at least fifty one percent of their investment within three years in order 106 Embassy in Lima to Department of State, “Call on President Velasco", June $11^{\text {th }} 1969$, Foreign Relations of the United States, 1969-1976, Volume E-10, Documents on American Republics, 1969-1972, eds. Douglas Kraft and James Siekmeier, (Washington: Government Printing Office, 2009), Document 631.

107 Unknown Author. Central Intelligence Agency Intelligence Bulletin, January $21^{\text {st }} 1972$. Central Intelligence Agency, [CIA CREST System, National Archives and Records Administration, Archives II, College Park, MD] CIA-RDP85T00875R000800020017 108 Roger Fontaine, The Andean Pact: A Political Analysis (Washington D.C.: Sage Publications, 1977), 12.

109 Ilya Prizel, Latin America Through Soviet Eyes: The Evolution of Soviet Perceptions (Cambridge: Cambridge University Press, 1990), 58. 
to give limit foreign influence in the Andean nations. ${ }^{110}$ Chile and Peru remained the most radical members of the group until Allende's death in 1973 and the overthrow of Velasco in 1975. Once they were removed the Andean Pact became far more involved in neoliberalism than nationalism. Yet, the Andean Common Market is an excellent example of how the left of center governments in Latin America attempted to move away from traditional dependence on the United States.

Despite the failure of the Andean Pact to create an economic bloc that could foster the growth of Andean industrial production, Peruvian policy did prove successful in preventing a negative U.S. response over its Cuban and Soviet relations and economic protectionism. In a March 1972 memorandum from the Assistant Secretary of State for Inter-American Affairs, Charles A. Meyer, to Henry Kissinger, the situation between the United States and Peru is concisely defined. "Our non-overt economic pressure policy has had little or no impact on the military government's determination to pursue a universality, but not necessarily anti-U.S., foreign policy. On the other hand, this policy has contributed to an adversary relationship between Peru and the U.S., which in turn, has provided opportunities for exploitation by the USSR."111 The document defined an acceptable relationship as one that promoted favorable trade and U.S. private investment, and longterm access to Peru's natural resources. U.S. market share of Peruvian exports decreased from 34\% in 1968 to 29\% in 1971 largely due to U.S. policy, and the willingness of Japan, the United Kingdom, and Germany to fill up the investment gap. The memorandum ends by

\footnotetext{
110 Roger Fontaine, The Andean Pact, 19.

111 Foreign Relations of the United Sates, 1969-1975, Volume E-10, Documents on American Republics, 1969-1972 Eds., 1, Douglas Kraft and James Siekmeier, (Washington: Government Printing Office, 2009), Document 638. https://history.state.gov/historicaldocuments/frus1969-76ve10/d638 Accessed May 2016.
} 
stating that a severe response from Peru would inevitability occur if the U.S. continued or increased pressure. Conciliatory action was clearly seen as being more beneficial as a diplomatic strategy. Peru successfully managed to play the United States and the Soviet Union off one another, while attempting revolutionary change. Peru's success in this manner cannot be understated especially as the nation was one of the poorest in the region and possibly the closest of Latin American nations towards the United States before 1968.

Drugs, the Peruvian Revolution, and the United States

One aspect that is neglected in the traditional narratives on the U.S.-Peruvian relationship during the revolutionary period is the subject of illicit drugs. Cocaine is produced from the coca plants grown in the Andes, and the growth of the cocaine industry worried both the United States and the Peruvian governments. Significantly, Peru led all of Latin America in drug arrests and seizures in the early 1970s. ${ }^{112}$ In 1971, The Bureau of Narcotics and Dangerous Drugs, later to become the Drug Enforcement Agency, began to work with Peruvian Law enforcement at the request of Peruvian officials. The Velasco regime feared the social ills that the increased drug trade would cause, and the government corruption that might accompany the growth of this illicit market. The Peruvian Investigations Police, PIP, wanted help filming coca plantations, and the Bureau of Narcotics and Dangerous Drugs, BNDD, began its attempt to set up a permanent office in

112 "Comments of Foreign Service Inspectors on BNDD Activities in Peru," U.S. Department of State, July 31, 1973, General Records of the Department of State, Bureau of International Narcotics Matters (1970-1978), Records Group 59, United States National Archives, Box 11, $1-2$. 
Lima. ${ }^{113}$ Paul Gootenberg's Andean Cocaine attributes the growth of the cocaine industry in Peru in the 1970s to the decreased social services of the weakened Velasco regime. The author states that the death of agricultural credits as well as lumber cooperatives created by the government forced farmers to begin producing coca leaves to support themselves. ${ }^{114}$ During the early stage of the drug war, the State Department provided only roughly $\$ 600,000$ dollars to help support the PIP, Peruvian Investigative Police's campaign against drug crimes. The growth of the drug trade in Peru terrified the Velasco regime especially with the increase in middle class drug use, and the State Department felt extremely pleased at the level of Peru's cooperation in combating the drug epidemic. One of the most startling cooperative efforts during the period involved the extradition of criminals to the United States.

Despite the nationalist rhetoric, Peru happily extradited multiple heads of drug operations as well as less valuable operatives. The deportation of Luis Reyes from Peru after his 208 pounds of cocaine were discovered in Miami brought the personal thanks of the director of the Bureau of Narcotics and Dangerous Drugs, John Ingersoll. ${ }^{115}$ Further extraditions of drug criminals occurred without the usual procedures that would have slowed down the process. These actions allowed Peru to increase U.S. aid for combating

\footnotetext{
113 "Additional Efforts to Improve Recipient Narcotics Control Capacity," U.S. Department of State. September 3, 1971, General Records of the Department of State, Bureau of International Narcotics Matters (1970-1978), Records Group 59, United States National Archives, Box 11, 1.

${ }^{114}$ Paul Gootenberg, Andean Cocaine (Chapel Hill: University of North Carolina Press, 2009), 296.

115 "Peruvian Cooperation with BNDD," December 21, 1971, General Records of the Department of State, Bureau of International Narcotics Matters (1970-1978), Records Group 59, United States National Archives, Box 11, 2.
} 
drugs with from $\$ 19,000$ in 1973 to a proposed increase of $\$ 400,000$ the next year. ${ }^{116}$ The State Department was clearly supporting Peru's rise as a regional leader in the fight against cocaine production. It is hard to imagine that the great deal of cooperation between Peru and the United States in support of the Drug War did not affect the decision to tolerate the revolutionary government, but future scholarship will have to prove the connection.

The 1970s changed the United States' ranking of Latin American in terms of importance on the world stage. ${ }^{117}$ Allende became Latin America's first democratically elected Marxist president in 1970, and forced the Nixon administration to really start paying attention to South America. Velasco's Peru played a strategic game of courting the United States one day, and antagonizing it the next. Appealing to nationalism allowed Peru to confiscate tuna boats, enact agrarian reform, and begin an Andean movement to promote economic independence. Despite enacting policies to move away from the traditional goals of U.S. foreign policy, Peru understood that its relationship with the United States needed to continue in order for Peru to remain economically stable for the shortterm future.

116 "Updated Narcotics Control Action Plan for Peru" September 17, 1973. General Records of the Department of State, Bureau of International Narcotics Matters (1970-1978), Records Group 59, United States National Archives, Box 11, 5.

117 Peru, Bolivia, and Ecuador all adopted left leaning policies to challenge the regional supremacy of the United States. The Nixon administration had to contend with an American public that was both fervently anti-communist and tired of foreign involvements after many years in Vietnam. 


\section{Chapter 4}

The first Soviet Military Sales in South America: Peruvian Agency in US-Peruvian Relations

Introduction

The Peruvian Revolution suffered setbacks in the first five years of its existence, but the majority of U.S. officials believed that the military government was firmly in power. Peru continued to press the United States for weaponry, but conflicts over tuna rights kept the United States from granting the Peruvian request. The Soviet Union happily filled the void, and brokered an arms deal with Peru in the summer of 1973. Instead of acting harshly, the United States changed policy toward Peru to be more conciliatory. An important factor in the long life of Velasco's regime was the lack of dissident generals for the United States to support. The years of turbulence between Peru and the United States ended after the Soviet arms deal for the simple fact that the United States needed an ally in the region, and the North American nation realized that continuing hostile policies could only drive Peru closer to its mortal enemy. The United States interests from 1973 to 1975 largely continued to be the same as they had since the Peruvian Revolution. The exception was the desire to prevent conflict between Peru and Chile and to keep Soviet influence in Peru to a minimum. The military government of Peru's interests during this time period were to maintain power, obtain more advanced weaponry, and become a more important player in the Third World.

In 1973, even as US-Peruvian relations were strained, these relations seemed poised to get worse. Cuba's demonstration of Soviet Arms to the Peruvian Military during a 
diplomatic meeting in December 1972 eventually lead to the Soviets providing the Andean nation more than $\$ 1.6$ billion dollars in equipment from 1973 to 1980.118 Peru became the second nation in Latin America to receive Soviet arms, but the United States' complacent response is even more startling. The simple rumors of Communist arms reaching Arbenz's Guatemala and similar actions in Allende's Chile drove the United States to support coups against their leaders. Why was Peru able to obtain significant Soviet arms without evoking a U.S. response while Guatemala's acquisition of poor quality small arms from Czechoslovakia; Chile's acquisition of the exact T-55 tanks that Peru would purchase a short time afterwards with no U.S. intervention? The diplomatic success of the Peruvian military regime is explained through four important characteristics of the time period and the historical importance of the US-Peruvian relationship. The historical tie between the U.S. and Peruvian military, the Nixon administration's greater trust for military governments and non-Marxists, and Peru's compensation for expropriating U.S. companies gave Peru the advantage that neither Guatemala nor Chile enjoyed. The last characteristic is that the U.S. simply needed an ally in the region and Peru could be trusted more than the other Andean nations.

The Legacy of US-Peruvian Military Ties is Key

The United States was and continues to be the major arms supplier to Peru as well as the rest of Latin America. Peru received over $\$ 59.3$ million dollars in military grants from the United States from 1950 until 1963.119 Military funding has always been an

118 Cynthia McClintock and Fabian Vallas, The United States and Peru: Cooperation at a Cost (New York: Routledge Press, 2003), 28.

119 Daniel Sharp. U.S. Foreign Policy and Peru, 38. 
extremely important part of foreign policy. The nation receiving the funding is often dependent on the materials, and this funding often comes with training that forges longterm connections between the nations. This funding in 1963 became a contentious issue as President Fernando Belaúnde refused to cut military spending even though it consumed a large part of the national budget. The United States wanted Peru to dedicate more resources to modernization. The rupture continued to grow after the United States' refusal to supply napalm to the Peruvian army during the 1965 counter-guerilla campaign. This deeply angered the Peruvian generals and led many to believe that the United States might not be as good a friend as they claimed. ${ }^{120}$ In 1967, the relationship worsened when a Peruvian loan request to the Inter-American Development Bank demanded a policy shift. The Inter-American Development Bank required Peru to reject the Peruvian Air Force's \$30 million dollar appeal for supersonic jets in order to be accepted.121 Belaúnde had been petitioning the State Department to purchase a number of F-5 fighter jets, but this new stipulation led Peru to purchase French Mirage jets instead. The United States condemnation unified the military and Peruvian people against the American economic and military domination of their nation. Negative responses from the North American nation would continually unite the many different factions of Peru and force the United States to be more conciliatory.

The revolution of 1968 distressed the U.S. officials, but diplomatic relations, which were suspended immediately, were renewed only twenty-three days later. The expropriation of the International Petroleum Company consistently damaged US-Peruvian relations during the military regime, and the threat of the enforcement of the Hickenlooper

120 Richard Walter, Peru and the United States, 1960-75, 78.

121 Walter, Peru and the United States, 1960-75, 100. 
amendment against Peru created headaches for both nations. The Hickenlooper amendment, introduced by Senator Bourke Hickenlooper of Iowa, in 1961 required the United States to end foreign assistance to any nation that expropriated U.S. related property without compensation within six months of the action. ${ }^{122}$ The State Department hated this stipulation as it drastically curtailed diplomatic flexibility. Time and time again U.S. officials, such as Ambassador Belcher and undersecretary for political affairs, U. Alexis Johnson, complained that the amendment was so heavy-handed that it became completely ineffective. ${ }^{123}$ Meanwhile, Nixon and his staff argued about the best course of action. Pushing too hard on Peru could turn the nation towards becoming a second Cuba. A powerful, leftist Peru could embolden other Latin American nations to follow its example..$^{124}$

Velasco and his foreign minister Mercado positioned themselves as leaders of the Third World with the United States being the imperial adversary as a way to keep the Peruvian public in support of the military regime, and to gain international standing to secure help. This way the United States would not be able to invoke punitive sanctions without both outraging the Peruvian public and worsening the regional situation in Latin America. 125

122 Walter, Peru and the United States, 1960-75, 26.

123 Walter, Peru and the United States, 1960-75, 208.

124 Hal Brands, "The United States and the Peruvian Challenge, 1968-1975," 478.

125 Central Intelligence Bulletin, February 11, 1969, Central Intelligence Agency [CIA CREST System, National Archives and Records Administration, Archives II, College Park, MD] CIARDP79T00975A013100020001-3 
Fishing in Troubled Waters: Tuna's effect on the US-Peruvian Relationship

Luckily for Peru, the Hickenlooper Amendment never resulted in the removal of foreign aid, but military sales were briefly suspended as part of the Pelly Amendment in February 1969 as a result of tuna boat seizures. ${ }^{126}$ The Pelly Amendment required the United States to end arms sales to any nation that seized American fishing vessels. Velasco, angry at U.S. suspension of military sales, responded by expelling part of the U.S. military. He reduced its mission down to only a seven men advisory team. The embassy in Lima noted that the Pelly Amendment's enforcement proved to many Peruvian officers that the United States really was not the friend it claimed to be and that the Amendment only proved that Peru would need to become more independent. The following May, a Peruvian military mission left to investigate weapons in France as well as several other European nations. ${ }^{127}$ Velasco used the opportunity to accuse the United States of giving up on the military assistance agreement of 1952. Military sales resumed later in 1969, but were once again removed in 1972 for the same reasons. For rest of the military regime's existence, the State Department would recommend using weapons purchases as a way to improve relations, but Congress would repeatedly stymie such attempts. ${ }^{128}$

Despite Nixon's policy shift towards a more accommodating stance, the Pelly Amendment still would not allow Peru to receive arms. An arms demonstration during a

${ }^{126}$ Central Intelligence Bulletin, February 11, 1969, Central Intelligence Agency [CIA CREST System, National Archives and Records Administration, Archives II, College Park, MD] CIARDP79T00975A013100020001-3190.

127 Central Intelligence Bulletin, May 22 1969, Central Intelligence Agency [CIA CREST System, National Archives and Records Administration, Archives II, College Park, MD] CIARDP79T00975A013800010001-6.

${ }^{128}$ Andrew Smith, American Tuna: The Rise and Fall of an Improbable Food (Berkeley: University of California Press, 2010), 127. 
trip to Cuba in December 1972 showed Peruvian officials the capability of modern Soviet weapons and accessibility of these armaments. Mercado once again asked for tanks but instead of light tanks offered before he asked for medium M-60 tanks. ${ }^{129}$ The U.S. Military Assistance Advisory Group continued to offer light tanks, and Peru subsequently decided to continue exploring the possibility of ordering the larger T-54 Soviet tanks. The United States feared that a harsh reaction could drive the domestic politics of Peru, already largely anti-U.S., towards better relations with the Soviet Union.

The tuna season of 1973 played an important role in the development of the SovietPeru relationship. The return of the fish to Peruvian waters attracted many U.S. fishermen and led to the Peruvian government's seizure of twenty-two of these vessels. ${ }^{130}$ Edgardo Mercado, now defense minister, reported to Ambassador Belcher that although Peru would prefer to have U.S.-made tanks, anger in Peru over U.S. encroachment on Peruvian fisheries might force his government to buy tanks from the Soviet Union. ${ }^{131}$ Peru began requesting new tanks from the United States in April of 1972 and were informed that M-41 Bulldogs were unavailable, but that M-551 Sheridans could possibly by obtained by the State Department. ${ }^{132}$ Peru desired heavier tanks, but the United States feared that this action could provoke an outright arms race with Chile. A month later, Foreign Minister Juan Mercado spoke directly to the American ambassador and stated that Soviet T-55 rated highly against American tanks and that the weapons came with very favorable loan rates,

\footnotetext{
129 “Peruvian Purchase Of Soviet Armament: Chronology Of Tank Purchase,” Wikileaks. June 30, 2005.

130 Richard Walter, Peru and the United States, 1960-75, 263.

131 Richard Walter, Peru and the United States, 1960-75, 264.

132 "Peruvian Purchase of Soviet Armament Chronology of Tank Purchase" Wikileaks, June $30^{\text {th }} 2005$.
} 
but Peru still preferred to obtain American weapons. ${ }^{133}$ Peru hoped that invoking the Soviet tank offer that the United States would be more accommodating.

However in 1973, since the Pelly amendment did not allow the American government to sell arms to Peru due to the 1972 tuna boat seizures, Velasco ordered tanks in the summer of 1973 from the USSR. ${ }^{134}$ A report from the new American ambassador to Peru, Taylor Belcher, noted that most Peruvians had little interest in the tank purchase, and the minority who were concerned had no ability to change the situation, "over the longer term, Peru's economic problems, e.g. coping with inflation and availability of foreign credit in short to medium term will pose far more serious problems for the stability of the Velasco government than the arrival of soviet arms."135

Mid-1973 bought an attempt to cajole Peru through a softer diplomacy approach with Nixon giving approval for both new loans from the World Bank and Inter-American Bank as well as loans for Peru to buy a number of F-5 fighter jets. ${ }^{136}$ The United States held great influence over international loans. The US president even overrode the punitive sanctions of the Pelly amendment for Peru as a sign of goodwill. This level of accommodation towards Peru by the U.S. is an excellent example of the belief that Washington needed the South American country's support.

Fortunately for Peru, the United States decided to do nothing about Peru's decision to buy Soviet tanks. The truly amazing part of this event was the reaction from the State Department. Kissinger instructed ambassador Belcher to inform Peru, "We do not question

133 "Peruvian Purchase Of Soviet Armament: Chronology Of Tank Purchase" Wikileaks. June 30, 2005.

134 Richard Walter, Peru and the United States, 1960-75, 265.

135 "Peruvian Purchase Of Soviet Arms: Internal

Reaction” Wikileaks. June 30, 2005.

136 Richard Walter, Peru and the United States, 1960-75, 274. 
Peru's sovereign right to buy arms wherever it chooses; but we are concerned at the entry of the Soviet Union into the Latin American arms market...The USG has every confidence that the GOP will thwart any Soviet attempts to meddle in Peru, but we do fear that the sale itself will produce a destabilizing effect in the Area."137 Peru's special position in American foreign policy, and its skilled diplomacy allowed it to avoid the usual aggressive U.S. response toward Latin American nations received when trying to obtain Soviet arms.

The Soviets in the Region

While the goals of U.S. policy are well defined, the Soviet Union's strategy in Latin America is rarely discussed. The Soviet Union wanted to develop allies in Latin America, in effect, to acquire natural resources and reduce U.S. influence in the region. ${ }^{138}$ However, the Latin American nations would not be allowed to expand power outside of the western hemisphere so much that it would damage relations between the United States and Soviet Union. The Soviet alliance with Cuba in the early 1960s scarred the Soviet mind in the aftermath of the Cuban Missile Crisis. The island nation would continually pursue an aggressive foreign policy, providing military support for rebels in Angola, Bolivia, and Nicaragua.

Allende reacted angrily to the news of Peru's signing a Soviet arms agreement as he had been considering the same action, and this event gave further impetus to the military

137 Department of State to Embassy in Peru, " Peruvian Purchase of Soviet Tanks. For Ambassador." January 24th 1974, Foreign Relations of the United States, 1969-1976, Documents on South America, 1973-1976. Sara Berndt, Halbert Jones, James Siekmeier Eds. 1. (Washington: United States Government Publishing Office, 2015), Document 293. https://history.state.gov/historicaldocuments/frus1969-76ve11p2/d293

138 Tobias Rupprecht, Soviet Internationalism after Stalin: Interaction and Exchange between the USSR and Latin America during the Cold War (Cambridge: Cambridge University Press, 2015), 232. 
to remove Allende for doing nothing to prevent Chile's traditional enemy from becoming more powerful. ${ }^{139}$ The rumors of a military coup in Chile made many Chileans wary that Peru would use the chaos and incoming Soviet arms to seize land lost during the War of the Pacific. The tension would continue even after Pinochet's successful coup in September 1973.

The United States was much less concerned about Soviet arms sales in the early 1970s as compared to two decades previously. In 1954, a striking contrast to the U.S. response to Peru occurred in Guatemala when President Jacobo Arbenz attempted to purchase arms from communist Czechoslovakia. Arbenz, an army officer who became president through a democratic election, expropriated estates held by U.S. companies as part of its efforts at land reform. ${ }^{140}$ The United States became increasingly suspicious of Arbenz's motives. Many of the unionists who supported the President were communists, and the military establishment began to fear for Guatemala's future. The rumors of a coup led Arbenz to order a shipment of Czechoslovakian small arms to arm a people's militia, which the United States used as a pretext to engineer his overthrow. ${ }^{141}$ The first arms transfer from the Soviet bloc to the Western hemisphere led to the overthrow of a democratically elected leader and began a history of U.S. sponsored coups against left leaning leaders around the world. Although one reason why the United States was less concerned about Soviet arms entering Peru as compared to Guatemala was Guatemala's proximity to the United States, and the regional situation in South America proved very

\footnotetext{
139 Ibid., 221.

140 John Charles Chasteen, Born in Blood and Fire: A Concise History of Latin America (Chapel Hill: University of North Carolina Press, 2001), 256.

141 Piero Gleijeses, Shattered Hope: The Guatemalan Revolution and the United States, 19441954, 279.
} 
different than in Central America. Geography proved to be destiny.

\section{The Regional Setting}

The regional situation in South America in the 1970s played an important role in allowing Peru to get Soviet arms without suffering repercussions. The United States always preferred military rule in Latin America to the generally unstable representative governments, but Nixon especially believed in the foundational power of militaries. On November 6, 1970, in reference to Allende's election, Nixon stated, "Let's not think about what the really democratic countries in Latin America say- the game is in Brazil and Argentina. We could have moves under the surface, which bring over time the same thing. I will never agree with the policy of downgrading the military in Latin America. They are power centers subject to our influence. We want to give them some help."142 For Nixon, it was easier for the United States to reassume hegemony in the southern cone through the support of military governments. The election provided an essential alternative viewpoint for leftism in Latin America as Peru became the country that the United States could work with rather than a Marxist Chile. ${ }^{143}$

From the beginning, the United States worked fervently to weaken and potentially end the Allende presidency. This included forcing international loan agencies such as the World Bank to deny loans to Chile, funding opposition parties, and working with Brazil to

\footnotetext{
142 "Memorandum of Conversation of a Meeting of the National Security Council" November 6, 1970, Foreign Relations of the United States, 1969-1976, Volume XXI, Chile, 1969-1973, eds. James McElveen and James Siekmeier Eds. 1. (Washington: Government Printing Office, 2014), Document 173.

${ }^{143}$ Hal Brands, "The United States and the Peruvian Challenge, 1968-1975," 480.
} 
change regional politics against the rising leftist tide. ${ }^{144}$ The United States increased the funding of the Chilean military during the Allende years to maximize contacts within the armed forces. ${ }^{145}$ Once the military dictatorship Augusto Pinochet ousted Allende in a coup in September 1973, the United States had another pro-U.S. government it could count on in the region.

While the United States fervently worked to rectify the situation in the Andes, another Latin American nations looked to the mountain and saw the potential for instability for the entire continent. In 1969, the military government of Emílio Garrastazu Médici took power in Brazil by ousting another military government. ${ }^{146}$ The Brazilian government argued that the United States could be doing more to combat Marxism in Latin America, and directly pleaded with the U.S. ambassador to work with Brazil to work against the Chilean government. Médici told Nixon in 1971 that his government had already been exchanging Brazilian military officers with Chilean officers to spread dissent, and the U.S. President made it clear that money and other help could be discreetly provided. ${ }^{147}$ No other nation would be so instrumental in defeating the Chilean president as Brazil. This relationship would be rewarded with the U.S. ignoring human rights violations in Brazil and the sale of F-5 fighter jets that had been blocked by the U.S. Congress. ${ }^{148}$ The Nixon administration's trust for military regimes that espoused anti-communist values once again trumped the rhetoric supporting healthy democracies. In another example, General Hugo

144 Tanya Harmer, Allende's Chile and the Inter-American System, 127.

145 Peter Kornbluh. The Pinochet File: A Declassified Dossier on Atrocity and Accountability. (New York: The New Press, 2013), 86.

146 Kornbluh, The Pinochet File, 99.

147 Kornbluh, The Pinochet File, 128.

148 Joseph Smith, Brazil and the United States: Convergence and Divergence (Athens: University of Georgia Press, 2010), 177. 
Banzer took power in Bolivia in 1970s, it too proved a stable, pro-U.S. force in the region.

With many, pro-U.S. military governments in South America, Washington could stomach Peru buying Soviet weapons.

\section{U.S. Softens its Policy towards Peru because of Peruvian Actions}

In September 1973, the United States decided to end its punitive sanctions against

Peru. Peruvians and U.S. businesses complained to the New York Times that the economic sanctions failed to have their desired effect, and Peru continued to attract investment from U.S. oil companies. ${ }^{149}$ The previous pressures from the United States lifted constituted a number of different techniques. The ban on arms sales, pressure from international lending agencies and New York banks against lending to Peru, and the pressure on major industrial nations with ties in Peru to reduce their economic relations with Peru all ended. ${ }^{150}$ U.S. officials apparently agreed. Secretary of Defense Elliot Richardson sent a secret memo to the Secretary of State, William P. Rogers, arguing that the United States should resume arms sales to Peru to prevent the Soviet Union from becoming too influential. ${ }^{151}$ The threat of Soviet influence through arms sales along with the failure of punitive sanctions forced the United States to make a major u-turn in how it dealt with the military government of Peru. The State Department considered a few alternatives, but any response that provoked an angry Peruvian backlash would be a problem. U.S. leaders wanted to maintain access to

149 New York Times (April 18, 1973), 8:1.

150 President's Assistant for National Security Affairs, Kissinger, to President Nixon, “Status Report Economic Pressures on Peru", April 17, 1969, Foreign Relations of the United States, 1969-1976, Volume E-10, Documents on American Republics, 1969-1972. eds. Douglas Kraft and James Siekmeier (Washington: Government Printing Office, 2009), Document 595.

https://history.state.gov/historicaldocuments/frus1969-76ve10/d595

151 Richard Walter, Peru and the United States, 1960-75, 270. 
Peruvian natural resources. ${ }^{152}$ The Soviet arms sales had forced the United States to change its foreign policy to be more conciliatory to Peru to keep the Latin American nation from moving closer to the Soviet Union.

However despite Nixon's earlier disinterest towards Latin America, the president admitted that he wanted to save Latin America from communist forces. Peru remained separate from Chile in American foreign policy due to its non-Marxist identification, and willingness to accept foreign private-sector investment. ${ }^{153} \mathrm{~A}$ pragmatic approach from the State Department and White House led the United States to accept leftist governments in Bolivia, Peru, and Ecuador, but still work against nations moving away from capitalism. Compensation for expropriation greatly helped to save Peru from the same fate as Chile. The military government claimed that the International Petroleum Company (IPC), the first target of expropriation, owed Peru almost $\$ 700$ million dollars in back taxes that needed to be paid in February 1969.154 The United States grew increasingly wary as Peru chose to expropriate Casa Grace, the decades old shipping, paper, and sugar conglomerate, in August the same year. ${ }^{155}$ Foreign minister Mercado deftly claimed the following month in an address to the United Nations General Assembly that Peru only expropriated companies that had contentious histories of inequality with the nation. A joint agreement between the military government and the Sheraton Hotel Company to build a modern complex in Lima greatly helped to validate the foreign minister's claim. The Velasco regime understood that survival depended on keeping the United States close enough with Peruvian affairs to placate the United States, but far enough that the Peruvian public would not believe that

152 “Peruvian Purchase of Soviet Arms: U.S. Policy Response." Wikileaks June 30, 2005.

153 Tanya Harmer, Allende's Chile and the Inter-American Cold War, 152.

${ }^{154}$ Lawrence Clayton, Peru and the United States: The Eagle and the Condor. 240.

155 Richard Walter, Peru and the United States, 1960-75, 209. 
the government did not really believe in putting the nation's interests first. Unfortunately for the military government, secret talks over compensating the International Petroleum Company became public knowledge in 1972 to great the embarrassment to Velasco. ${ }^{156}$ In 1974, the negotiations for Peruvian compensation for IPC concluded when the governments of Peru and the United States Special Presidential Representative James Greene negotiated the Greene Settlement. 157 The International Petroleum Company, Casa Grace, and other U.S. companies nationalized by Peru received $\$ 76$ million dollars in compensation paid by Peru, but distributed by the United States. ${ }^{158}$ Robert Dean, Belcher's replacement for ambassador to Peru, summed up perfectly the strategy to keep Peru in the U.S. fold as well as the reasons for why the United States remained so flexible towards the Latin American nation in the telegram to the Secretary of State.

"U.S. Security Assistance to Peru helps to dispose this militarily ruled country more favorably to our overall interests, notably access to natural resources, and it reduces what is obtained from communist sources. In terms of the effectiveness of such assistance it has helped to keep Peru in the inter-American defense system and has molded favorably the attitude of many of the current and also future officers who rule and will probably continue ruling Peru."159

Peru's purchase of Soviet arms did not end with tanks in December of 1973. A failure to reach an agreement on aircraft purchases with the United States led to the USSR's first military arms sale to any Latin American nation in the May of $1975 .{ }^{160}$ Thirty Soviet-Made

\footnotetext{
156 Hal Brands, "The United States and the Peruvian Challenge, 1960-1975," 481.

157 Foreign Relations of the United States, 1969-1976, Documents on South America, 19731976. Sara Berndt, Halbert Jones, and James Siekmeier eds 1, (Washington: Government Printing Office, 2014), Document 296.

158 "Peru" National Intelligence Bulletin. December 21 1974, CIARDP79T00975A02730010008-0 159 "Security Assistance Objectives and Guidelines for Peru" June 21 $11^{\text {st }} 1974$, Wikileaks, June 30th 2005. https://wikileaks.org/plusd/cables/1974LIMA05010 b.html 160 "Peru Buys First Soviet Military Aircraft" May 6 1975, CIARDP79T01098A000500060002-4
} 
Mi-8 helicopters, 200 T-55 Tanks, and an unknown number of 122 and $130 \mathrm{~mm}$ howitzers, SU-22 fighter-bombers, trunk mounted BM-21 rocket launchers, and ZSU-23-4 anti-aircraft guns became part of Peru's new arsenal. ${ }^{161}$ The US that supplied the majority of Peru's weaponry before the revolution was reduced to supplying 30 percent in 1975. Moreover the United States' close military relationship with Peru seemed threatened when Peru welcomed at least thirty-five Peruvians traveled to the Soviet Union to receive air defense training. The Velasco regime continued until 1975 when the general fell to a coup by more conservative military leaders. It is clear that Peru succeeded in resisting American influence in arms sales and continued cooperate with the Soviet Union after the United States changed its non-overt punitive policies.

\section{Implications of this study}

The entrance of Soviet arms into Peru posits an important question to historians. Why did the United States allow the recalcitrant nation to obtain such weapons without enacting harsh penalties? The most direct answers are pure economics and ideology. Compensation for expropriated businesses and the disavowal of Marxism gave the Velasco government the ability to survive its move away from U.S. influence, while Allende's Chile could not. U.S. officials apparently agreed with U.S. businessmen that the economic sanctions were actually counterproductive and changed the punitive policies. The regional situation of Latin American politics in the early 1970s forced the United States to accept left leaning allies in its fight against communism. Leftists came to power in Ecuador, Bolivia, and Peru during this period, and President Nixon did not react the same way to these

161 “The Latin American Arms Market” December 17 1975, CIA-

RDP86T00608R0005001080020-7 
nations as he did to Chile. Peru's unusual left leaning military dictatorship allowed the nation to move away from the United States while simultaneously negotiating with its traditional ally to keep essential support flowing. The Peruvian experiment ended in August of 1975, but the legacy of Juan Velasco Alvarado continued with the recent Leftist president Ollanta Humala from 2011 to 2016.

The historiography of the US-Peruvian relationship in the $20^{\text {th }}$ century is small compared to the numerous volumes about Chile, but it is equally rich. However there has been relatively little written focusing on Peruvian agency in this relationship. Walters' Peru and the United States, $1960-1975$ is by the far the most comprehensive and important work in the historiography that focuses on the direct actions of the military government in how U.S. foreign policy developed during those years. Frederick Pike's The United States and the Andean Republics is seminal in introducing the regional aspect, but it does not highlight the role of Latin Americans enough.

This work is adding to a trend in the historiography that highlights Latin American agency into the change of U.S. foreign policy. Hal Brands' Latin America's Cold War and James Siekmeier's Bolivian Revolution and the United States place a far greater importance on the actions of elite and non-elite Latin Americans in the shaping of Cold War politics in the Western Hemisphere than previous authors. Alan McPherson's The Invaded examines Latin American responses to U.S. military invasions in the early 1900s to explain the eventual end of this form of imperialism. These works have contributed to the trend of adding the importance of work done by Latin Americans to the historiography of U.S. foreign relations. The diplomatic finesse by the Peruvian government during the late 1960s and early 1970 s directly contributed to U.S. accommodation to the regime. Any 
examination into U.S. foreign policy is insufficient without studying the actions and intentions of the foreign power. 
Bibliography

Primary Sources

Central Intelligence Agency, CREST System, National Archives Research Administration Building Two, College Park Maryland

Foreign Relations of the United States, 1969-1976, Volume E-10, Documents on American Republics, 1969-1972, eds, Douglas Kraft and James Siekmeier (Washington: Government Printing Office, 2009. https://history.state.gov/historicaldocuments/frus1969-76ve10

Foreign Relations of the United States, 1969-1976, Volume XXI, Chile, 1969-1973, eds. James McElveen and James Siekmeier Eds. 1. (Washington: Government Printing Office, 2014 https://history.state.gov/historicaldocuments/frus1969-76v21

General Records of the Department of State, Bureau of International Narcotics Matters (19701978), Records Group 59, United States National Archives, Box 11.

\section{Secondary Sources}

Andrea, Carol. Carol Andrea. When Women Rebel: The Rise of Popular Feminism in Peru. Westport: L. Hill Publishing, 1985.

Brands, Hal. Latin America's Cold War. Cambridge: Harvard University Press, 2010. Hal Brands, "The United States and the Peruvian Challenge, 1968-1975" Diplomacy \& Statecraft 21, 2010. 
Carey, James. Peru and the United States, 1900-1962. Notre Dame: University of Notre Dame Press, 1964.

Christenson, Joel. "From Gunboats to Good Neighbors: U.S. Naval Diplomacy in Peru, 1919-1942." (Ann Arbor, Proquest Publishing, 2013),

Clarke, Nathan. "Revolutionizing the Tragic City: Rebuilding Chimbote, Peru, after the 1970 Earthquake" Journal of Urban History, Vol 4, 93-115 2015.

Clayton, Lawrence. Peru and the United States: The Condor and the Eagle. Athens: University of Georgia Press, 1999

Cotler, Julio. The Cambridge History of Latin America. Cambridge: Cambridge University Press, 2008.

Flindell Klarén, Peter. Peru: Society and Nationhood in the Andes. Cambridge: Harvard University Press, 2000.

Fontaine, Roger. The Andean Pact: A Political Analysis. Washington D.C.: Sage Publications, 1977.

Heilman, Jaymie. Before the Shining Path: Politics in Rural Ayacucho, 1895-1980. Palo Alto: Stanford University Press, 2010

Kofas, Jon V. Foreign Debt and Underdevelopment: U.S.-Peruvian Economic Relations. Lanham: University Press of America, 1996.

Kornbluh, Peter. The Pinochet File: A Declassified Dossier on Atrocity and Accountability. New York: The New Press, 2013.

Kruijit, Dirk. Revolution by Decree: Peru 1968-1975. West Lafayette: Purdue University Press, 2003.

McClintock, Cynthia and Abraham F. Lowenthal. The Peruvian Experiment 
Reconsidered. Guildford: Princeton University Press, 1983.

McClintock, Cynthia and Fabian Vallas. The United States and Peru: Cooperation at a Cost

New York: Routledge Press, 2003.

McClintock Cynthia. Peasant Cooperatives and Political Change in Peru Princeton: Princeton University Press, 1981.

Pineo, Ronn. Ecuador and the United States: Useful Strangers. Athens: University of Georgia Press, 2007.

Pike, Frederick. The United States and the Andean Republics: Peru, Bolivia, and Ecuador. Cambridge: Harvard University Press, 1977.

Prizel, Ilya. Latin American Through Soviet Eyes: The Evolution of Soviet Perceptions. Cambridge: Cambridge University Press, 1990.

Rabe, Stephen. The Most Dangerous Area in the World: John F. Kennedy Confronts Communism in Latin America. Chapel Hill: University of North Carolina Press, 1999.

Shaleth, Maria R. “Land Reform Under Military: Agrarian Reform in Peru, 1969-78.” Economic and Political Weekly, Vol. 26, No. 30 July 27, 1991.

Sharp, Daniel. U.S. Foreign Policy and Peru. Austin: University of Texas Press, 1972.

Siekmeier, James. The Bolivian Revolution and the United States, 1952 to the Present. University Park: Pennsylvania State University Press, 2011

Starn, Orin. The Peru Reader. Durham: Duke University Press, 2005.

Tsurumi, Rebecca. The Closed Hand: Images of the Japanese in Modern Peruvian Literature. West Lafayette: Purdue University Press, 2010.

Walker, Thomas W. and Christine J. Wade. Nicaragua: Living in the Shadow of the 
Eagle. Boulder, Westview Press, 2011.

Walter, Richard. Peru and the United States, 1960-1975: How their Ambassadors Managed Foreign Relations in a Turbulent Era. University Park: Pennsylvania State University, 2010.

Yglesias, Jose."Report from Peru: The Reformers in Brass Hats: The reformers in brass hats" New York Times, (1923-Current files); Dec 14, 1969. 